\title{
Male and Female Mice Lacking Neuroligin-3 Modify the Behavior of Their Wild-Type Littermates
}

\author{
Shireene Kalbassi, ${ }^{\circledR}$ Sven O. Bachmann,* Ellen Cross,* ${ }^{*}$ Victoria H. Roberton, and ${ }^{\circledR}$ Stéphane J. \\ Baudouin
}

DOI:http://dx.doi.org/10.1523/ENEURO.0145-17.2017

School of Biosciences, Cardiff University, Cardiff CF10 3AX, Wales

\begin{abstract}
In most mammals, including humans, the postnatal acquisition of normal social and nonsocial behavior critically depends on interactions with peers. Here we explore the possibility that mixed-group housing of mice carrying a deletion of NIgn3, a gene associated with autism spectrum disorders, and their wild-type littermates induces changes in each other's behavior. We have found that, when raised together, male Nlgn3 knockout mice and their wild-type littermates displayed deficits in sociability. Moreover, social submission in adult male Nlgn3 knockout mice correlated with an increase in their anxiety. Re-expression of Nlgn3 in parvalbumin-expressing cells in transgenic animals rescued their social behavior and alleviated the phenotype of their wild-type littermates, further indicating that the social behavior of Nlgn3 knockout mice has a direct and measurable impact on wild-type animals' behavior. Finally, we showed that, unlike male mice, female mice lacking Nlgn3 were insensitive to their peers' behavior but modified the social behavior of their littermates. Altogether, our findings show that the environment is a critical factor in the development of behavioral phenotypes in transgenic and wild-type mice. In addition, these results reveal that the social environment has a sexually dimorphic effect on the behavior of mice lacking Nlgn3, being more influential in males than females.
\end{abstract}

Key words: Autism spectrum disorders; neuroligin; parvalbumin interneurons; social behavior

\section{Significance Statement}

Several studies have shown that the behavior and physiology of socially dominant mice differs from that of socially submissive mice. Despite this knowledge, no study has so far addressed the influence of group inequality, and in particular social hierarchy, on behavioral and Physiological measures obtained in mouse models of autism spectrum disorders and their wild-type littermates. In this study, we used a mouse model lacking the Nlgn3 gene and demonstrated that, indeed, transgenic mice and their wild-type littermates can modify each other's behavior. These observations could profoundly affect experiments using mouse models of psychiatric disorders, as they suggest that the use of wild-type littermate mice as controls may lead to misinterpretation of results.

\section{Introduction}

In the majority of mammalian species, social groups are not egalitarian but organized in social hierarchies that can influence individuals' behavior and stress. For example, in despotic hierarchies, the dominant individuals are more anxious than the submissive ones, whereas the contrary
Received April 24, 2017; accepted July 9, 2017; First published July 31, 2017. Authors report no conflict of interest.

Author contributions: S.K., S.O.B., E.C., and S.J.B. performed research; S.K., S.O.B., E.C., and S.J.B. analyzed data; S.K., V.H.R., and S.J.B. wrote the paper; S.J.B. designed research and contributed unpublished reagents/analytic tools.

This work was supported by the Life Science Research Network Wales, an initiative funded through the Welsh Government's Ser Cymru program, and by 
is found when the dominance is maintained through intimidation (Sapolsky, 2005). Inbred laboratory mice establish highly stable social hierarchies maintained through intimidation from the dominant male to the submissive males (Wang et al., 2011). Because of laboratory housing conditions, intimidations from dominant mice cannot be avoided, meaning that male dominance behavior is likely to raise anxiety levels in submissive individuals (Sapolsky, 2005). Indeed, studies show that social hierarchy can be a stressor for submissive animals and increase their motoric activity (Van Loo et al., 2003; Vargas-Pérez et al., 2009). Social rank also affects animals' physiology; for example, socially submissive animals show decreased mRNA expression levels of corticotropin-releasing hormone receptor 2 and estrogen receptor $\alpha$ in the brain (Greenberg et al., 2014). Although mouse social hierarchies have only been well characterized in adult male laboratory mice (Wang et al., 2011), the potential existence of social hierarchies in groups of young or female laboratory mice cannot be excluded (Schuhr, 1987; Vom Saal et al., 1995; Garner et al., 2016).

Many mouse models for autism spectrum disorders (ASD) show social behavior defects and traits associated with social submission (Wang et al., 2011), namely courtship vocalization and territorial defects (Spencer et al., 2005; Kazdoba et al., 2016). The effect of social submission on phenotypes associated with ASD remains elusive but has been shown to influence courtship vocalization behavior of mice with a 16p11.2 microdeletion, a model for ASD (Yang et al., 2015a). Social environment can also have a positive impact on the phenotype of mouse models for ASD and rescue their sociability deficits (Yang et al., 2011). Although the effect of the social environment on phenotypes in mouse models for ASD is starting to be understood, the impact on the behavior of peers within the social housing group remains largely unknown. We speculated that rearing mouse models for ASD with nondeficient wild-type littermates might be sufficient to cause measurable behavioral and physiologic changes in all mice within the social environment.

Many genetic mouse models related to so-called syndromic forms of ASD display complex sets of phenotypes (Kazdoba et al., 2014; Portmann et al., 2014) not all directly related to autism. To minimize complexity, we have used a model of nonsyndromic ASD in which mice lack the X-linked gene Nlgn3, coding for the postsynaptic adhesion protein Neuroligin-3 exclusively expressed in the brain (Tanaka et al., 2010; Baudouin et al., 2012). In

funds to S.J.B and E.C. from the Wellcome Trust, UK. The authors declare no conflict of interest.

*S.O. Bachmann and E. Cross contributed equally to this work.

Acknowledgments: We thank Y. Barde and G. McNamara for insightful comments on this manuscript and J. Hurst and L. Wilkinson for expert advice. We thank Adam Ranson for providing the Pvalb $b^{\text {Cre/Cre mice. }}$

Correspondence should be addressed to Stéphane J. Baudouin. E-mail: BaudouinS@cardiff.ac.uk.

DOI:http://dx.doi.org/10.1523/ENEURO.0145-17.2017

Copyright ( $\odot 2017$ Kalbassi et al.

This is an open-access article distributed under the terms of the Creative Commons Attribution 4.0 International license, which permits unrestricted use, distribution and reproduction in any medium provided that the original work is properly attributed.

\begin{tabular}{|c|c|c|c|c|c|}
\hline \multicolumn{6}{|c|}{ Experiments in males } \\
\hline Dams & Sires & litters obtained & acronym & symbc & figures \\
\hline \multirow{3}{*}{$\mathrm{Nlgn}^{++-}$} & \multirow{3}{*}{$\mathrm{Nlgn} 3^{\mathrm{y} /+}$} & only $\mathrm{N} \operatorname{lgn} 3^{y /+}$ & SGH & ? & \multirow{3}{*}{1 to 5} \\
\hline & & only Nlgn3/- & SGH & - & \\
\hline & & $N \operatorname{lgn} 3^{y /+}$ and $N \operatorname{lgn} 3^{y /-}$ & MGH & - 0 & \\
\hline $\begin{array}{l}\text { Pvalh }^{+/+} \\
\mathrm{Nlgn3}^{+/ 2}\end{array}$ & $\begin{array}{l}\text { Pvalb cre/cre } \\
\text { Nlgn3 } 3^{y /+}\end{array}$ & 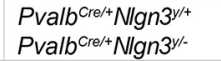 & & $\bullet$ & 3,4 \\
\hline
\end{tabular}

\begin{tabular}{|c|c|c|c|c|c|}
\hline \multicolumn{6}{|c|}{ Experiments in females } \\
\hline Dams & Sires & litters obtained & acronym & symbc & figure: \\
\hline $\mathrm{N} / g n 3^{-\mu}$ & Nlgn $3^{y /-}$ & only $\mathrm{Nlgn}^{-}$ & SGH & $\bullet$ & 4,6 \\
\hline $\mathrm{Nlgn}^{+/-}$ & Nlgn $3^{y /-}$ & $\mathrm{Nlgn}^{--}$and $\mathrm{Nlgn}^{+/-}$ & $\mathrm{H}-\mathrm{KO}$ & $\circ \cdot$ & 4,6 \\
\hline $\mathrm{Nlgn}^{+/-}$ & $\mathrm{Nlgn} 3^{y /+}$ & $\mathrm{Nlgn} 3^{+/+}$and $\mathrm{Nlgn}^{+/ /}$ & H-WT & - 0 & 6 \\
\hline
\end{tabular}

Figure 1. Summary of the breeding schemes.

humans, NLGN3 deletion is associated with nonsyndromic ASD (Jamain et al., 2003; Ylisaukko-oja et al., 2005; Levy et al., 2011; Sanders et al., 2011; C Yuen et al., 2017). The deletion of N/gn3 in mice leads to distinct measurable phenotypes, including social behavior and courtship deficits (Radyushkin et al., 2009; Fischer and Hammerschmidt, 2011; Baudouin et al., 2012; Rothwell et al., 2014). Moreover, behavioral phenotypes in Nlgn3 $3^{y /-}$ are mediated by deficits in the balance between excitation and inhibition in the striatum and long-term depression in the cerebellum (Baudouin et al., 2012; Rothwell et al., 2014; Zhang et al., 2015). Here, we show that male mice lacking NIgn3 are socially submissive to their wild-type littermates and that this social submission correlates with increased anxiety in Nlgn3 knockout mice. We find that the behavior of male and female mice lacking Nlgn3 modifies the social behavior of their littermates. Importantly, we show that re-expression of Nlgn3 in parvalbuminexpressing interneurons in $\mathrm{Nlgn}^{\mathrm{y} /-}$ mice rescues their social submission phenotype and the corresponding effect on the wild-type littermates, thus confirming that the behavior of mutant mice is causing the social behavior phenotype in their wild-type littermates.

\section{Materials and Methods}

\section{Animals}

All animal husbandry and experiments were performed in compliance with the UK Animals (Scientific Procedures) Act 1986, as amended, and in accordance with the Cardiff University animal care committee's regulations. Mice containing a stop cassette flanked by loxP sites in the promoter region lacking Nlgn3 expression (N/gn3 $3^{y /-}$ \#RBRC05451; Tanaka et al., 2010) and mice expressing Cre recombinase under the Pvalb endogenous promoter in Pvalbexpressing cells (Pvallbre/Cre mice JAX:017320; Hippenmeyer et al., 2005) were backcrossed to a $\mathrm{C} 57 \mathrm{BI} / 6$ background for at least eight generations. Male and female mice were separated at weaning but housed only with their own littermates. For a summary of the breeding schemes, refer to Fig. 1. Breeding between $\mathrm{Nlgn}^{+/-}$mice and $\mathrm{Nlgn}^{\mathrm{y/t}}$ mice produced $50 \% \mathrm{Nlgn}^{\mathrm{y/+}}$ and $50 \% \mathrm{Nlgn}^{\mathrm{y}^{\mathrm{y}-}}$ mice. We therefore obtained litters that contained both $\mathrm{Nlgn}^{\mathrm{y} /+}$ and $\mathrm{Nlgn}^{\mathrm{y} / \mathrm{-}}$ mice [referred to as mixed genotype housing $(\mathrm{MGH})]$ and, at a lower frequency, litters in which males were all of the same genotype, $\mathrm{Nlgn} 3^{y /+}$ or $N \operatorname{lgn} 3^{y /-}$ mice [referred to as single genotype housing (SGH)]. Importantly, mice from SGH only ever encountered mice of the 

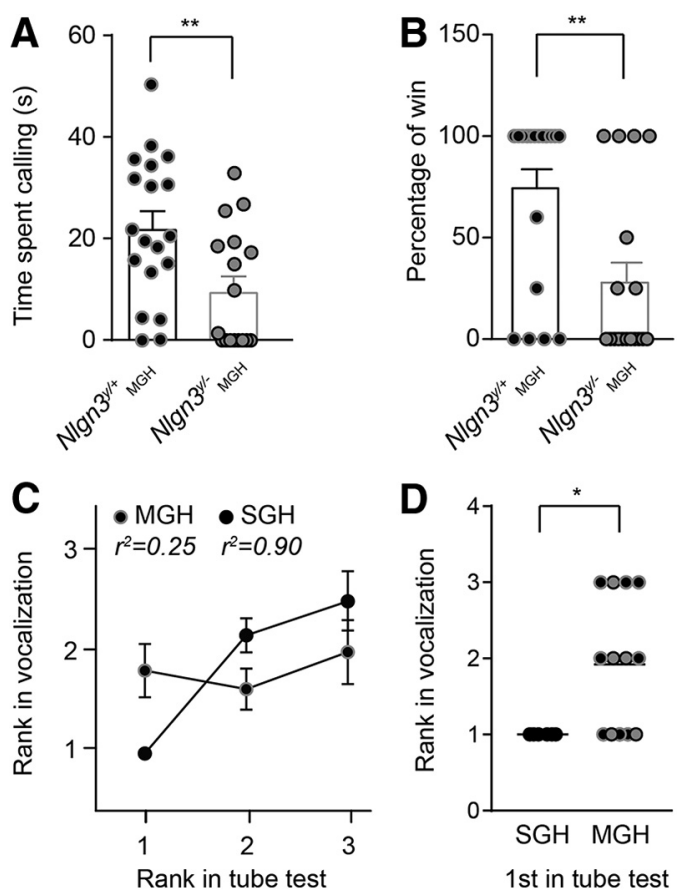

Figure 2. Adult $\mathrm{Nlgn}^{\mathrm{y} /-}$ mice (2-4 mo old) are submissive to their $\mathrm{Nlgn}^{\mathrm{y} /+}$ littermates. Littermate groups were composed of (1) $N \operatorname{lgn} 3^{y /+}$ mice in SGH and (2) $N \operatorname{lgn} 3^{y /+}$ and $N \operatorname{lgn} 3^{y /-}$ mice in

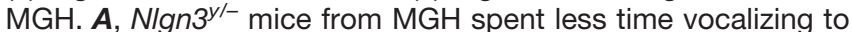
a female in estrus compared with $\mathrm{Nlgn}^{y /+}$ from $\mathrm{MGH}$. B, $\mathrm{N} / g n 3^{y /-}$ mice from MGH lost more frequently in the tube test against their $\mathrm{Nlgn}^{\mathrm{y} /+}$ littermates. $\mathrm{C}$, Absence of correlation between rank in the tube and ultrasonic vocalization tests in MGH mice. $\boldsymbol{D}$, For each group of mice from SGH and MGH, we plotted the rank in the vocalization test for the mice that were dominant in the tube test. All mice from SGH that won in the tube test also vocalized the most, and 5 of 13 mice from MGH (38\%) that won in the tube test vocalized the most. For mice from MGH, black dots with gray circles are $N / g n 3^{y /+}$ mice, and gray dots with black circles are $\mathrm{Nlgn}^{\mathrm{y} /-}$ mice. Values are represented as mean \pm SEM. Statistical significance was tested by two-tailed $t$ test $(\boldsymbol{A})$ and two-tailed Mann-Whitney test $(\boldsymbol{B}$ and $\boldsymbol{C}) ; * P<0.05$; $* * P<0.01$

same genotype. $\mathrm{Nlgn}^{+/-}$mice were crossed with $N / g n 3^{y /+} P v a l b^{c r e / c r e}$ mice to generate litters containing $\mathrm{Nlgn}^{\mathrm{y} /+} \mathrm{Pvalb}^{\mathrm{cre} /+}$ and $\mathrm{Nlgn} 3^{\mathrm{y} /-} \mathrm{Pvalb}{ }^{\mathrm{cre} /+}$ mice (Figs. 2-6). $\mathrm{Nlgn}^{+/-}$mice were crossed with $\mathrm{Nlgn} 3^{y /-}$ males to generate litters containing $\mathrm{Nlgn}^{-1-}$ mice in $\mathrm{MGH}$, and $\mathrm{Nlgn}^{-1}{ }^{-}$mice were crossed with $\mathrm{Nlgn}^{\mathrm{y} /-}$ males to generate litters containing $\mathrm{Nlgn}^{-/-}$mice in SGH (Fig. 5). $\mathrm{Nlgn}^{+/-}$mice were crossed with $\mathrm{Nlgn}^{\mathrm{y} /+}$ male mice to generate litters containing $\mathrm{Nlgn}^{+/+}$and $\mathrm{Nlgn}^{+/-} \mathrm{H}-\mathrm{WT}$ mice, and $\mathrm{Nlgn}^{+/-}$mice were crossed with $N \operatorname{lgn} 3^{y /-}$ males to generate litters containing $\mathrm{Nlgn}^{+/-}{ }_{\mathrm{H}-\mathrm{KO}}$ and $\mathrm{Nlgn}^{-/-}$mice (Fig. 7). Sires were separated from pregnant dams, and mice were weaned at postnatal day 30 (P30) to avoid the potential confounds associated with weaning on mice tested at P21-P28.

Mice were kept on a 12-h light/dark cycle with free access to food and water. All behavior was assessed during the light cycle. Experiments in adult mice were conducted when mice were 2-4 mo old (Figs. 2-4, 6, and
7) and in young mice at P21-P28 (Fig. 5). To minimize anxiety associated with human handling, all mice were well handled before testing (Hurst and West, 2010). On the testing day, mice were habituated for $30 \mathrm{~min}$ to the testing room and handled with minimal restraint to reduce anxiety (Hurst and West, 2010). Tests were conducted over several days always in the following order: activity, marble burying, interest in social odors tests, courtship vocalization, and tube test. Note that all mice did not undergo testing in all tasks (refer to Statistical analysis).

\section{Interaction with females and ultrasonic vocalization}

Before experiments, vaginal smears were stained with modified Giemsa solution (fixative and blue/azure dye) to determine the stage of estrus cycle (Caligioni, 2009). Test male mice were first habituated for $3 \mathrm{~min}$ to the arena. Subsequently, an unfamiliar female mouse in estrous was added to the same arena for $3 \mathrm{~min}$. An experimenter blind to genotype manually scored interaction times. Interaction was recorded when mice were within $2 \mathrm{~cm}$ of each other. Ultrasonic vocalizations were recorded using an UltraSoundGate $416 \mathrm{H}$ preamplifier connected UltraSoundGate CM16 microphone (Aviosft Bioacoustics) and quantified automatically using SASLabPro software (Aviosft Bioacoustics). As previously described (Holy and Guo, 2005), events within the frequency range $30-200 \mathrm{~Hz}$ and longer than $5 \mathrm{~ms}$ were quantified, and the time spent calling was measured.

\section{Tube test}

Social dominance within cages was assessed using the tube test apparatus (Noldus). This consists of a smooth transparent acrylic tube (length, $30 \mathrm{~cm}$; internal diameter, $3.5 \mathrm{~cm}$ ) with automated doors at both entrances and in the center. All mice were habituated to the tube for at least $10 \mathrm{~min} / \mathrm{d}$ over at least $4 \mathrm{~d}$. On testing days, mice were placed at opposite ends of the tube and released to enter the tube. When mice reached the center of the tube, the middle door opened and mice were challenged to push their opponent out of the tube. The mouse pushed out of the tube was declared the submissive mouse of that trial. To determine the cage hierarchy, mice from each cage were tested in pairs in a round-robin design, ensuring that all pairings of mice had been tested. The sides of entry for the mice were alternated to avoid bias. The test was repeated three times every $5 \mathrm{~d}$, and the hierarchy on the third testing day was quantified. For testing using unfamiliar mice, we identified submissive C57BI/6 mice using tube and ultrasonic vocalization tests before testing, and each test mouse encountered three different submissive mice. The percentage of wins, (number of wins)/(total number of encounter) $\times 100$, was quantified.

\section{Spontaneous activity and elevated plus maze}

Spontaneous activity of mice was recorded in a $40 \times$ $20-\mathrm{cm}$ open field (OF) arena for $20 \mathrm{~min}$ in the dark using an infrared video camera. EthoVision XT tracking software (Noldus) was used to measure the distance traveled in the OF (average centimeters traveled per second) and the normalized distance traveled in the center of the arena (5 $\mathrm{cm}$ from the wall), expressed as (distance traveled in the 

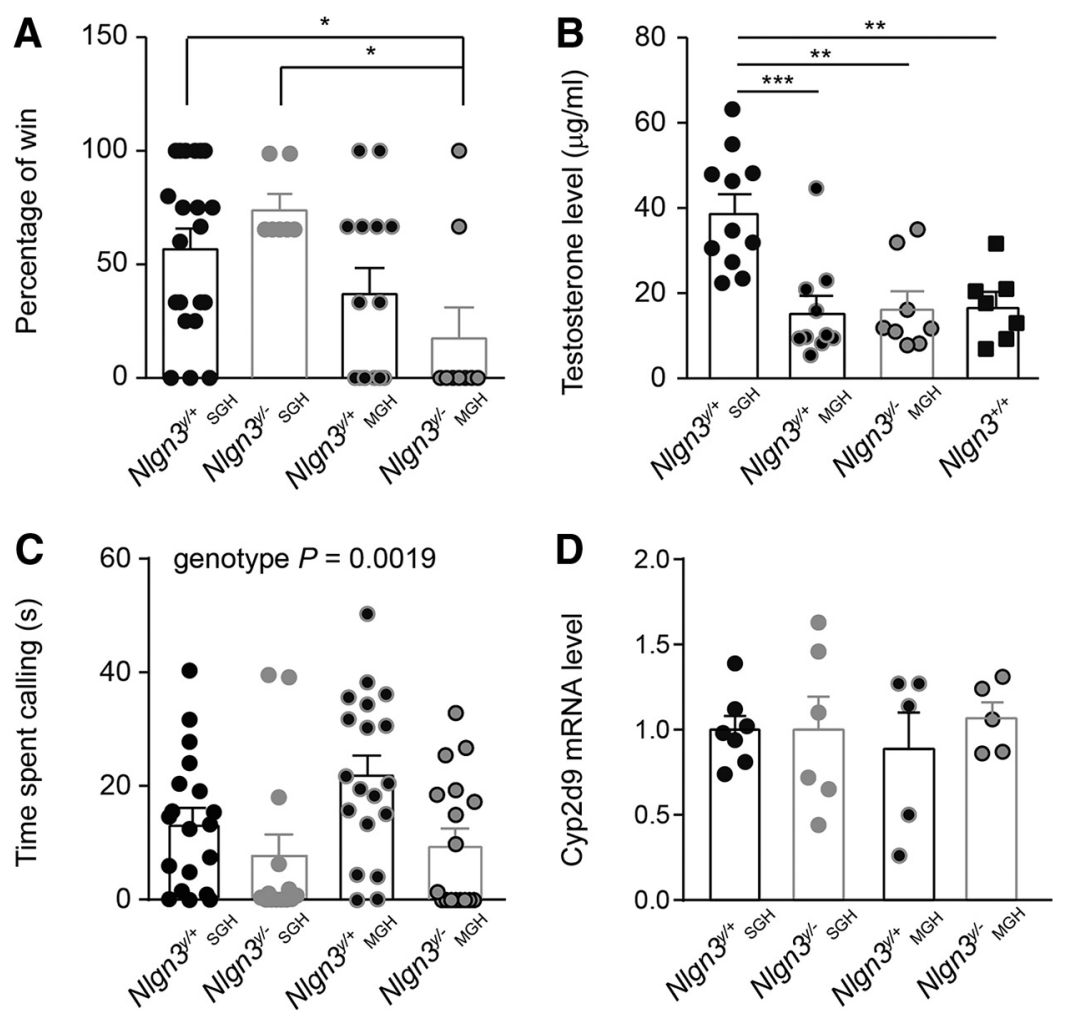

Figure 3. Decreased competitive behavior in adult (2- to 4-mo-old) $N / g n 3^{y /-}$ and $N \operatorname{lgn} 3^{y /+}$ mice from MGH. $\boldsymbol{A}, \mathrm{Nlgn} 3^{y /-}$ mice from $\mathrm{MGH}$ were defeated more frequently than $\mathrm{Nlgn}^{y /+}$ and $\mathrm{Nlgn} 3^{y /-}$ mice from SGH when opposed to an unfamiliar submissive male in the tube test. $\boldsymbol{B}$, Increased urinary testosterone levels in $\mathrm{Nlgn}^{y /+}$ mice from SGH. C. Housing conditions did not modify the time $\mathrm{Nlgn} 3^{y /+}$ or $N / g n 3^{y /-}$ mice spent calling a female in estrus. Regardless of the housing conditions, $N / g n 3^{y /-}$ mice spent less time calling a female in estrus than $\mathrm{Nlgn}^{\mathrm{y}^{/+}+}$mice. Note that data from Fig. $2 A$ were replotted here to allow comparison. $\boldsymbol{D}$, Hepatic mRNA expression levels of Cyp2d9 were similar between mice in MGH and SGH. Values are represented as mean \pm SEM. Statistical significance was tested by Kruskal-Wallis test and post hoc Tukey's multiple comparison test ( $\boldsymbol{A}$ and $\boldsymbol{B})$ and one-way ANOVA and post hoc Tukey's multiple comparison test $(\boldsymbol{C}$ and $\boldsymbol{D})$. $* P<0.05 ; * * P<0.01 ; * * * P<0.001$.

center of the OF)/(total distance traveled in the OF). For spontaneous activity over $30 \mathrm{~h}$, mice were individually housed in clear cages $(40 \times 24 \times 18 \mathrm{~cm})$ with free access to food and water and maintained on their standard light/ dark cycle. Three infrared beams passed the bottom part of the cage. Total beam breaks were recorded over $33 \mathrm{~h}$, the first $3 \mathrm{~h}$ corresponding to a phase of habituation to the cages and the next $30 \mathrm{~h}$ to the testing phase. For the elevated plus maze (EPM), mice were placed for $5 \mathrm{~min}$ in a maze composed of four perpendicular $40-\mathrm{cm}$ arms, two opposite arms with high walls, and two other opposite arms without walls. The exploration of the EPM was recorded by a computer-linked video camera located above the arena, and the time spent in the open arms was quantified using EthoVision XT.

\section{Interest in social odors}

Social odors originated from two cages of three C57BI/6 male mice with different parental origins, maintained for $6 \mathrm{~d}$ with the same home cage bedding to allow for a concentration of odorants. Before the test, swabs were wiped in a zigzag pattern across the bottom surface of the cage to collect the olfactory cues. Mice were acclimatized for 30 min to the presence of a cotton swab before testing. For the experiment presented in Fig. $4 A$, the following odors were presented in sequence: water, water, banana, banana, and social odor. During the 2-min exploration periods, the time spent sniffing the swab on the first exposure to each odor was recorded manually. For the experiment presented in Fig. $4 B$, a swab containing a social odor and a swab without odor were presented in two identical cups placed in opposite corners of the open field. Mice were able to be in direct contact with the odors, and exploration behavior was recorded over $4 \mathrm{~min}$. The time spent in proximity to the social odor $(<10 \mathrm{~cm}$ from the swab) was quantified using tracking software.

\section{Marble burying}

Mice were placed in individual cages $(28 \times 17 \mathrm{~cm})$ that each contained 20 marbles arranged in rows of four, on top of 4-cm-deep bedding, to allow burying behavior. The room used was dimly lit, with equal light distribution for all mice in the trial. In the days before testing, mice were habituated to the test cage for 30 $\min$. On test days, mice were left for $30 \mathrm{~min}$ in the test cage containing the marbles. Marbles were manually counted and defined as buried when $>50 \%$ of the marble was hidden. For quantification, experimenters were blind to the genotype. 

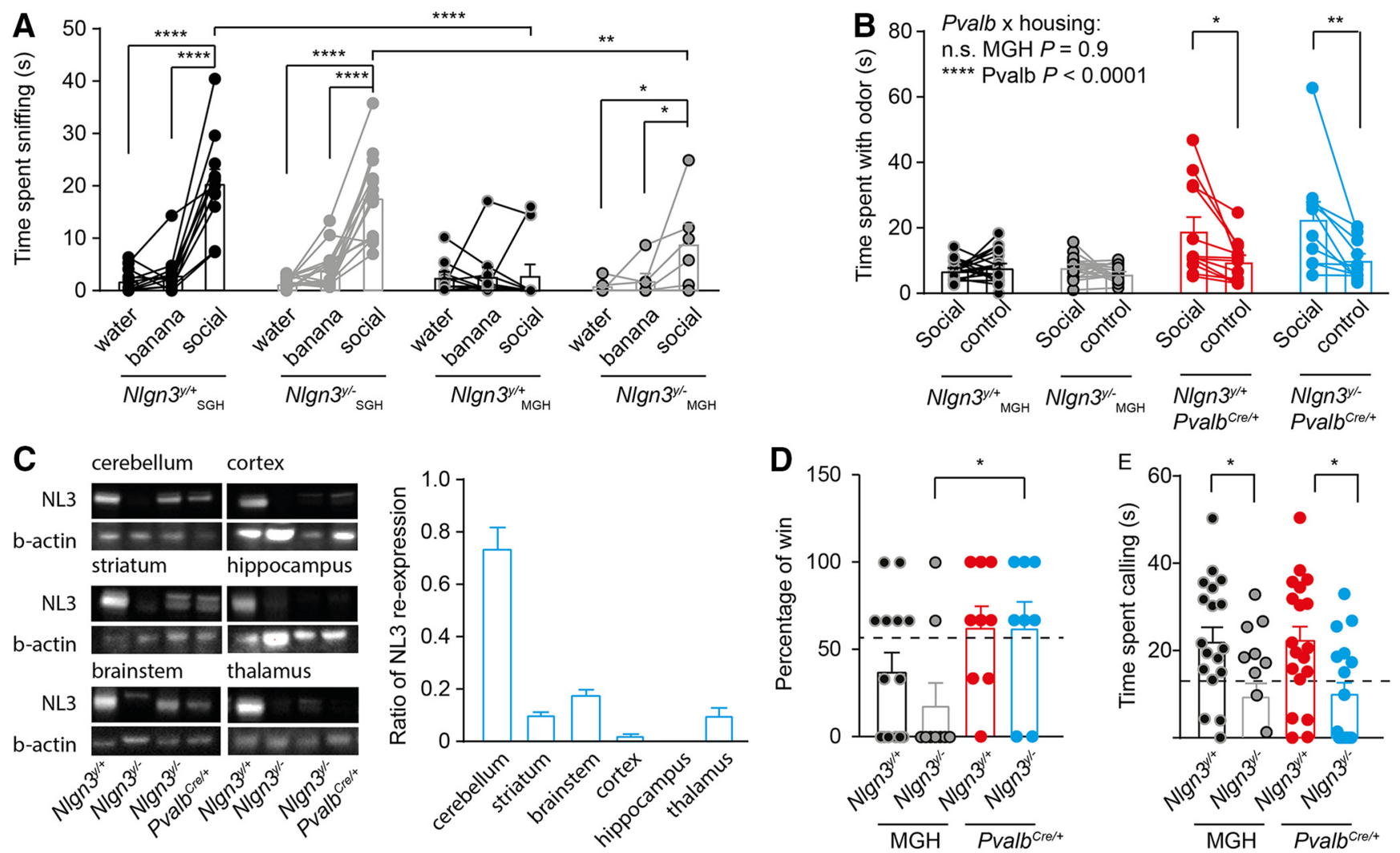

Figure 4. Adult (2- to 4-mo-old) $\mathrm{NIgn} 3^{y /-}$ mice modify the social behavior of their littermates. A, Nlgn $3^{y /+}$ and $N / g n 3^{y /-} \mathrm{mice}$ from SGH and $\mathrm{NIgn}^{\mathrm{y} /-}$ mice from $\mathrm{MGH}$ showed increased interest in social odors compared with water, whereas this increased interest was absent in $\mathrm{NIgn}^{y /+}$ mice from MGH. Note that $N \operatorname{lgn} 3^{y /+}$ and $\mathrm{Nlgn} 3^{y /-}$ mice from SGH spent more time sniffing the social odor

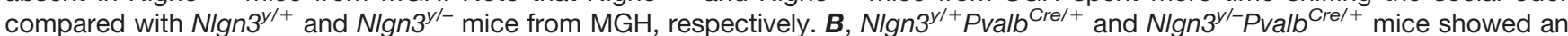
increased interest for social odors compared with $\mathrm{Nlgn}^{\mathrm{y/t}}$ and $\mathrm{N} / \mathrm{gn} 3^{\mathrm{y} / \mathrm{-}}$ mice from $\mathrm{MGH}$. C. Western blot analysis shows a ratio of re-expression of 0.7 in the cerebellum, 0.15 in the brainstem, 0.1 in the striatum, 0.1 in the thalamus, and 0.04 in the cortex and no re-expression in the hippocampus. Note that the upper band in the brainstem $\mathrm{Nlgn}^{y /-}$ sample is most likely unspecific, as it appears in protein samples from $N \operatorname{lgn} 3^{y /-}$ mice. $\boldsymbol{D}, \mathrm{Nlgn} 3^{y /-}$ and $N \operatorname{lgn} 3^{y /+}$ mice from MGH lost more frequently against an unfamiliar submissive mouse compared with $\mathrm{Nlgn}^{y /-} \mathrm{Pvalb} \mathrm{Cre}^{\mathrm{C}+}$ and $\mathrm{Nlgn} 3^{\mathrm{y} /+} \mathrm{Pvalb} \mathrm{Cre}^{\mathrm{Cr}+}$ mice. No difference in the percentage of wins against an unfamiliar submissive male was found in the tube test between $\mathrm{Nlgn}^{y /+} \mathrm{Pval} \mathrm{b}^{\mathrm{Cre} /+}$ and $\mathrm{Nlgn} 3^{\mathrm{y} /-} \mathrm{Pvalb} \mathrm{Cre}^{\mathrm{C}+}$ mice. Note that $\mathrm{Nlgn} 3^{y /+}$ and $\mathrm{Nlgn} 3^{y /-}$ mice from MGH data are replotted from Fig. $3 A$. The dotted line represents the mean percentage of wins for $\mathrm{Nlgn} 3^{y /+} \mathrm{mice}$ from SGH. $\boldsymbol{E}, \mathrm{Nlgn}^{y /-}$ mice from MGH and $\mathrm{Nlgn} 3^{y /-} \mathrm{Pvalb} \mathrm{Cre}^{\mathrm{C}+}$ mice spent less time calling a female in estrus than $\mathrm{Nlgn} 3^{y /+}$ mice from MGH and Nlgn $3^{y /+}$ Pvalb ${ }^{C r e /+}$ mice, respectively. The dotted line represents the mean time sent calling for $N$ lgn $3^{y /+}$ mice from SGH, replotted from Fig. $3 B$. Values are represented as mean \pm SEM. Statistical significance was tested by two-way ANOVA repeated-measures $(\boldsymbol{A})$, two-way ANOVA $(\boldsymbol{B}, \boldsymbol{D}$, and $\boldsymbol{E})$, and post hoc Sidak's multiple comparison test. $* P<0.05 ; * * P<0.001 ; * * * * P<0.0001$.

\section{Testosterone dosage}

Urine was collected from the mice immediately after bladder voiding and frozen instantly on dry ice. The urine was then stored at $-20^{\circ} \mathrm{C}$ until testosterone quantification. Testosterone was quantified using ELISA in accordance with manufacturer instructions (Arbor Assays).

\section{RNA isolation and quantitative real-time PCR}

Total RNA from liver was isolated with TRlzol reagent (Thermo Fisher Scientific) and purified using the RNeasy kit (Qiagen). cDNA was synthesized using Superscript III (Thermo Fisher Scientific). Quantitative real-time PCR analysis was performed using Fast SYBR green Master Mix (Thermo Fisher Scientific) on a real-time PCR System (Thermo Fisher Scientific). Relative expression levels were determined by normalization to 18S rRNA expression using the comparative $\Delta \Delta \mathrm{C}_{\mathrm{T}}$ method. Primers used were Cyp2d9 forward, 5'-AGTCTCTGGCTTAATTCCTGAT-3',
Cyp2d9 reverse, 5'-CGCAAGAGTATCGGGAATGC-3', $18 \mathrm{~S}$ forward, 5'-GTCTGTGATGCCCTTAGATG-3', and 18 S reverse' 5'-AGCTTATGACCCGCACTTAC-3'.

\section{Western blot}

Brain regions were dissected from adult mice after death and immediately frozen in liquid nitrogen. A volume of $100 \mathrm{ml}$ lysis buffer was added to $10 \mathrm{mg}$ tissue [50 mM Tris- $\mathrm{HCl}, 1 \mathrm{~mm}$ EDTA, $0.1 \%$ sodium dodecyl sulfate, 150 $\mathrm{mm} \mathrm{NaCl}, 1 \%$ Triton X-100, $10 \mathrm{~mm} \mathrm{NaF}, 1 \mathrm{~mm} \mathrm{NaVO}_{4}, 1$ $\mathrm{mm}$ dithiothreitol, and complete protease inhibitor (SigmaAldrich)]. The amount of protein in each sample was quantified using a bicinchoninic acid protein assay. Samples were then diluted in lithium dodecyl sulfate buffer (106 mm Tris- $\mathrm{HCl}, 141 \mathrm{~mm}$ Tris-base, 2\% lithium dodecyl sulfate, $10 \%$ glycerol, $0.51 \mathrm{~mm}$ EDTA, $0.22 \mathrm{~mm}$ G250 Coomassie Blue, $0.175 \mathrm{~mm}$ Phenol Red, and $10 \mathrm{~mm}$ DTT, $\mathrm{pH}$ 8.5), and $25 \mathrm{mg}$ of each sample was loaded onto 

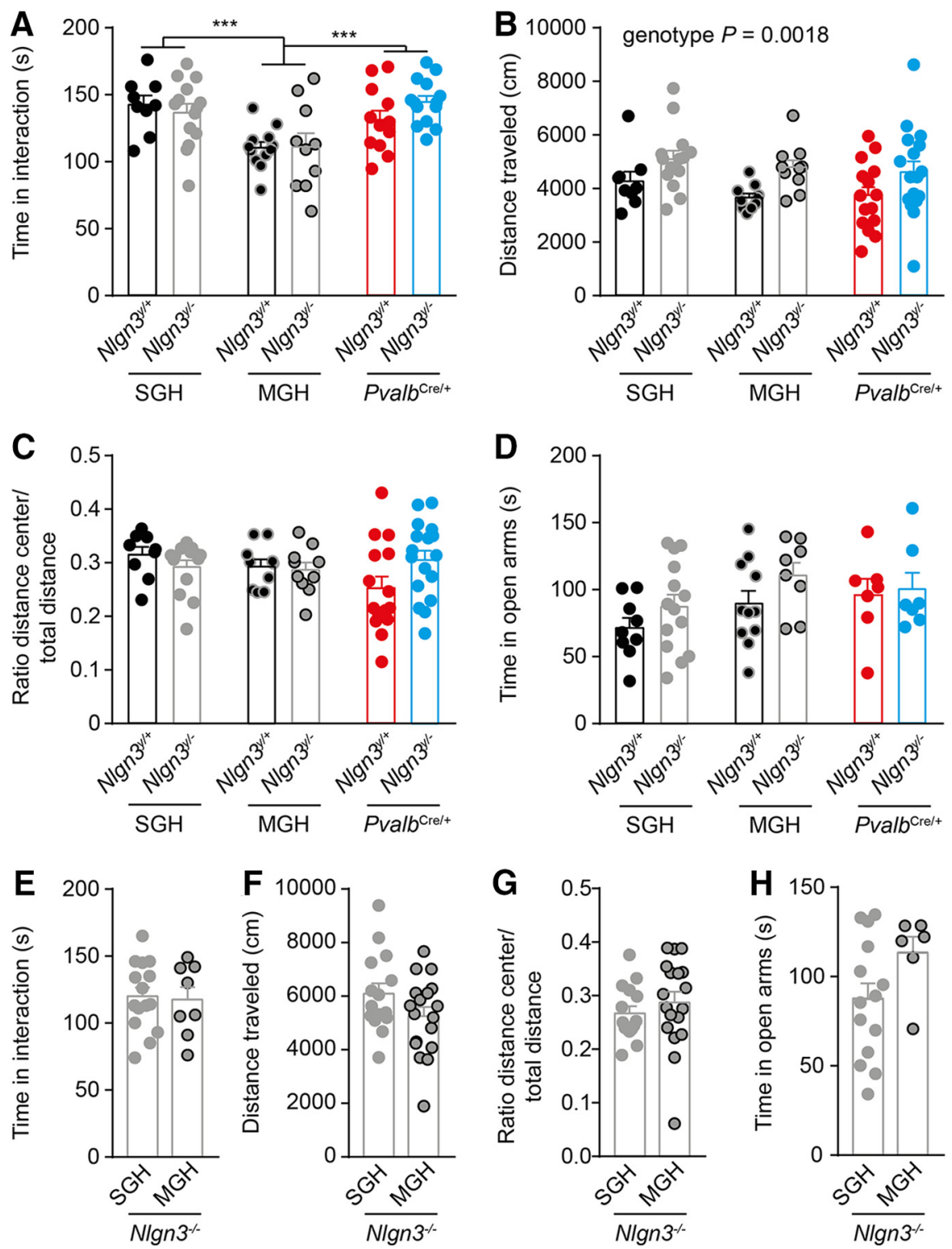

Figure 5. In young mice (P21-P28), MGH modifies the interest in social interaction of $\mathrm{Nlgn}^{y /+}$ and $\mathrm{Nlgn}^{\mathrm{y/-}}$ but not $\mathrm{Nlgn3^{-/ }}$ mice. $\boldsymbol{A}$,

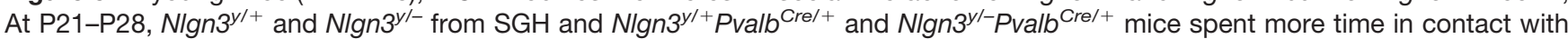
an unfamiliar female than $\mathrm{Nlgn}^{y /+}$ and $\mathrm{Nlgn}^{y /-}$ mice. B, C, No difference in the total distance and the normalized distanced traveled in the center of the OF. $\boldsymbol{D}$, No difference in the time spent in the open arms of the EPM. $\boldsymbol{E}-\boldsymbol{H}$, MGH has no significant effect on the time spent in social interaction, the total distance and normalized distance traveled in the center of the OF, and the time spent in the open arm of the EPM of females lacking $\mathrm{Nlgn} 3\left(\mathrm{Nlgn}^{-/-}\right)$. Values are represented as mean \pm SEM. Statistical significance was tested by two-way ANOVA and post hoc Sidak's multiple comparison test $(\boldsymbol{A}-\boldsymbol{C})$. $* * * P<0.001$.

4-12\% Bis-Tris polyacrylamide gels and transferred onto nitrocellulose membranes. Rabbit monoclonal anti-Neuroligin-3 (Abcam; clone EPR16158) and chicken anti- $\beta$ actin (Abcam; clone 2G10) antibodies were used. Signals were detected using horseradish peroxidase and Alexa Fluor 488-conjugated secondary antibodies (Thermo Fisher Scientific). The level of re-expression was quantified as (Neuroligin-3/actin) in $\mathrm{Nlgn} 3^{y /-} \mathrm{Pvalb}^{\mathrm{Cre} /+}$ mice normalized to (Neuroligin-3/actin) in $\mathrm{Nlgn}^{\mathrm{y} /+}$ mice.

\section{Statistical analysis}

Table 1 contains the data structure, type of test used, observed power, and $n$ for each figure. Each test included enough animals to reach a power close to or higher than 0.8 . Mice were not systematically tested for all tasks. We designed our test groups to have mice from the different groups tested at the same time. We used GraphPad Prism to systematically test for normality using the D'AgostinoPearson test and for outliers using the regression and outlier removal (ROUT) method with $Q=1$ to ensure that no outliers would modify the outcome and power of the statistical tests. No animals were removed from the analyses. For each experiment, at least three independent litters were analyzed. Pairwise comparisons were analyzed by two-tailed Student's $t$ test for normally distributed datasets or two-tailed Mann-Whitney test for non- 
Table 1. Details of statistical analysis

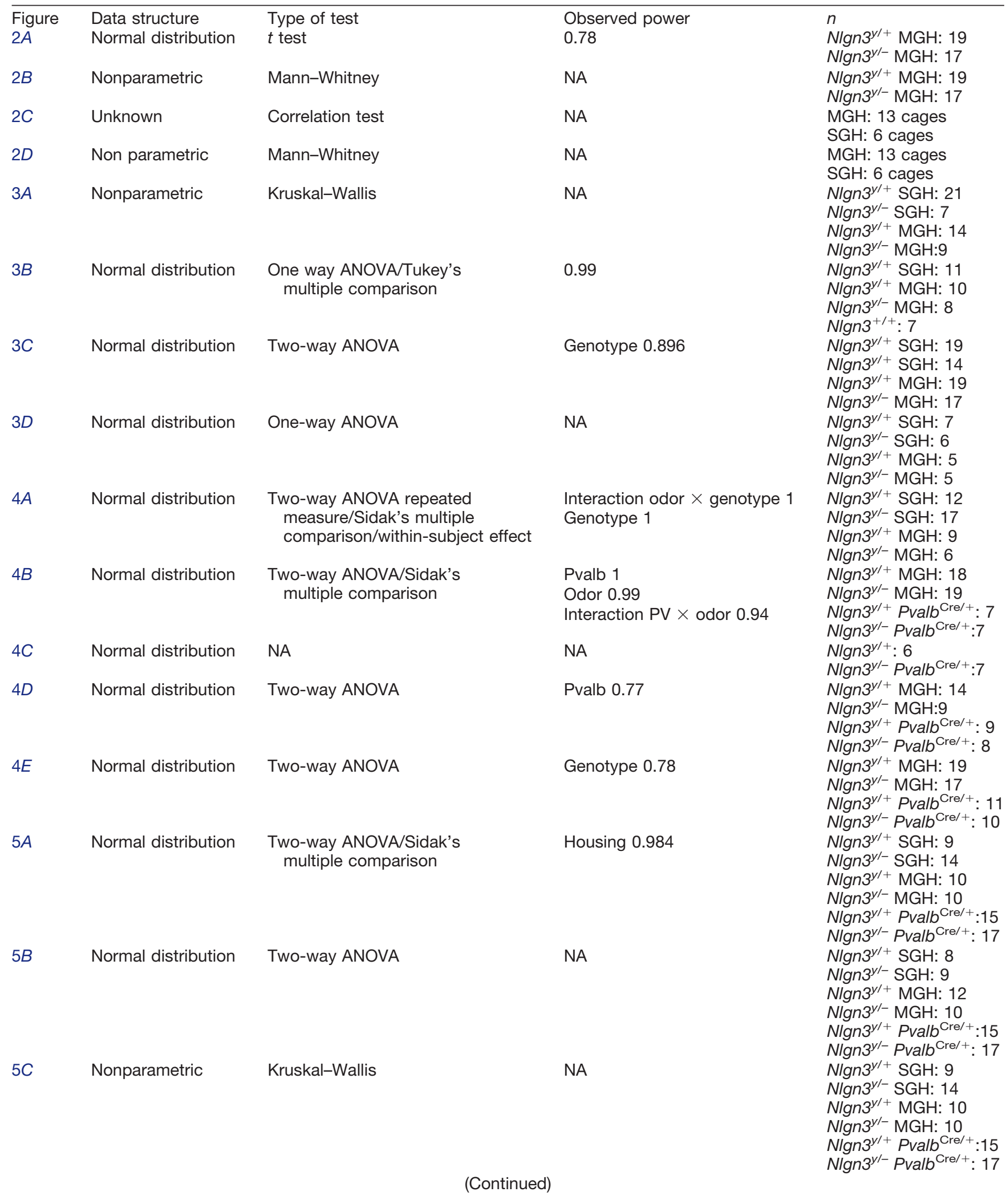

normally distributed datasets. Multiple comparisons were performed using one-way ANOVA for normally distributed datasets or Mann-Whitney test for non-normally distrib- uted datasets, followed by Tukey's or Dunn's post hoc tests for multiple comparisons when appropriate. All datasets used for two-way nonrepeated and repeated- 
Table 1. Continued

\begin{tabular}{|c|c|c|c|c|}
\hline Figure & Data structure & Type of test & Observed power & $n$ \\
\hline $5 D$ & Normal distribution & Two-way ANOVA & NA & 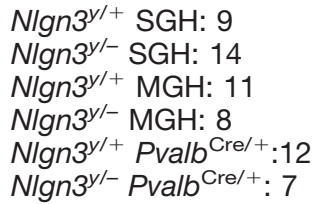 \\
\hline $5 E$ & Normal distribution & $t$ test & NA & $\begin{array}{l}\text { Nlgn3 }^{-/} \text {SGH: } 15 \\
\text { Nlgn3 }^{-/-} \mathrm{MGH}: 8\end{array}$ \\
\hline $5 F$ & Normal distribution & $t$ test & NA & $\begin{array}{l}\text { Nlgn3 }^{-/-} \text {SGH: } 15 \\
\text { Nlgn3 }^{-/-} \text {MGH: } 18\end{array}$ \\
\hline $5 G$ & Nonparametric & Mann-Whitney & NA & $\begin{array}{l}\text { Nlgn3 }^{-/-} \text {SGH: } 15 \\
\text { Nlgn3 }^{-/-} \mathrm{MGH}: 18\end{array}$ \\
\hline $5 H$ & Normal distribution & $t$ test & NA & $\begin{array}{l}\text { Nlgn3 }^{-/-} \text {SGH: } 14 \\
\text { Nlgn3 }^{-/-} \text {MGH: } 6\end{array}$ \\
\hline $6 A$ & Normal distribution & $\begin{array}{l}\text { Two-way ANOVA/Sidak's } \\
\text { multiple comparison }\end{array}$ & $\begin{array}{l}\text { Housing } 0.83 \\
\text { Interaction } 0.672\end{array}$ & $\begin{array}{l}\text { Nlgn3 } 3^{y /+} \text { SGH: } 16 \\
\text { Nlgn3 } \\
\text { Nlgn } 3^{y /-} \text { SGH: } 12 \\
\text { Nlgn } 3^{y /-} \text { MGH: } 26\end{array}$ \\
\hline $6 B-C$ & Normal distribution & Two-way ANOVA & NA & $\begin{array}{l}\text { Nlgn } 3^{y /+} \text { SGH: } 6 \\
\text { Nlgn3 } 3^{y /-} \text { SGH: } 11 \\
\text { Nlgn3 } 3^{y /+} \text { MGH: } 10 \\
\text { Nlgn } 3^{y /-} \text { MGH: } 9\end{array}$ \\
\hline $6 B$ & Normal distribution & $\begin{array}{l}\text { Two-way ANOVA/Sidak's } \\
\text { multiple comparison }\end{array}$ & $\begin{array}{l}\text { Genotype } 0.997 \\
\text { Interaction } 0.987\end{array}$ & $\begin{array}{l}\text { Nlgn } 3^{y /+} \text { SGH: } 16 \\
\text { Nlgn3 } \\
\text { Nlgn } 3^{y /-} \text { SGH: } 12 \\
\text { NIgn } 3^{y /-} \text { MGH: } 26\end{array}$ \\
\hline $6 E$ & Normal distribution & $\begin{array}{l}\text { Two-way ANOVA/Sidak's } \\
\text { multiple comparison }\end{array}$ & $\begin{array}{l}\text { Genotype } 0.76 \\
\text { Genotype } 0.52\end{array}$ & $\begin{array}{l}\text { Nlgn } 3^{y /+} \text { SGH: } 11 \\
\text { Nlgn3 } 3^{y /-} \text { SGH: } 16 \\
\text { Nlgn3 } \\
\text { Nlgn } 3^{y /-} \text { MGH: } 10\end{array}$ \\
\hline $7 A$ & Normal distribution & $\begin{array}{l}\text { One way ANOVA/Tukey's } \\
\text { multiple comparison }\end{array}$ & 0.99 & 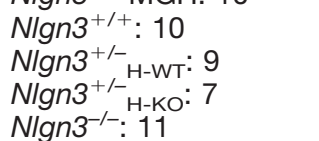 \\
\hline $7 B$ & Nonparametric & $\begin{array}{l}\text { Kruskal-Wallis/Dunn's } \\
\text { multiple comparison }\end{array}$ & 0.94 & $\begin{array}{l}\text { Nlgn3 }^{+/+}: 10 \\
\text { Nlgn3 }^{+/-}{ }^{+\mathrm{H}-\mathrm{WT}}: 9 \\
\text { Nlgn3 }^{+/-}{ }^{-\mathrm{H}-\mathrm{KO}}: 12 \\
\text { Nlgn3 }^{-/-}: 18\end{array}$ \\
\hline $7 C$ & Normal distribution & $\begin{array}{l}\text { One way ANOVA/Tukey's } \\
\text { multiple comparison }\end{array}$ & 0.96 & $\begin{array}{l}\text { Nlgn3 }^{+/+}: 10 \\
\text { Nlgn3 }^{+/-}{ }^{\text {H-WT }}: 9 \\
\text { Nlgn3 }^{+/-}{ }^{\text {H-KO }}: 12 \\
\text { Nlgn3 }^{-/-}: 18\end{array}$ \\
\hline $7 D$ & Normal distribution & One way ANOVA & NA & $\begin{array}{l}N^{\prime g n n} 3^{+/+}: 8 \\
\text { Nlgn3 }^{+/-}{ }^{\mathrm{H}-\mathrm{WT}}: 5 \\
\text { Nlgn3 }^{+/-}{ }^{\mathrm{H}-\mathrm{KO}}: 11 \\
\text { Nlgn3 }^{-/-}: 7\end{array}$ \\
\hline
\end{tabular}

NA, not applicable.

measure ANOVAs were normally distributed and, when appropriate, followed by post hoc Sidak's test. All statistical data are presented as mean \pm SEM.

\section{Results}

To investigate the role of social hierarchy in the behavior of $\mathrm{Nlgn} 3^{y /-}$ mice and their wild-type $\left(\mathrm{Nlgn}^{\mathrm{y} / \mathrm{f}}\right)$ littermates, we analyzed the behavior of mice from litters consisting of both genotypes (MGH) in comparison to litters in which male mice were all of the same $\mathrm{Nlgn} 3^{\mathrm{y} /+}$ genotype (SGH). As previously reported (Radyushkin et al., 2009; Fischer and Hammerschmidt, 2011), Nlgn $3^{y /-}$ mice from MGH emitted fewer ultrasonic vocalizations during courtship in comparison to $\mathrm{Nlgn}^{\mathrm{y} /+}$ from $\mathrm{MGH}$ $\left[N \operatorname{lgn} 3^{y /+} 22.2 \pm 3.5 \mathrm{~s}\right.$ and $N \operatorname{lgn} 3^{y /-} 9.8 \pm 2.8 \mathrm{~s}, P=0.007$,
$F_{(18,16)}=1.49$; Fig. 2A]. Additionally, in the tube test, $\mathrm{Nlgn3}^{y /-}$ mice from MGH lost more frequently when competing against $\mathrm{Nlgn}^{\mathrm{y} /+}$ mice from $\mathrm{MGH}\left(\mathrm{Nlgn}^{\mathrm{y} /+}\right.$ $72.9 \% \pm 9.8 \%$ and $N \operatorname{lgn} 3^{y /-} 29.4 \% \pm 10.3 \% ; P=0.0074$; Fig. $2 B$ ), suggesting that they are socially submissive to their wild-type littermates (Wang et al., 2011). In groups of mice with a stable social hierarchy, there is a correlation between ranking in courtship vocalization and in the tube test (Wang et al., 2011). The dominant mouse vocalizes the most and wins in the tube test, and the most submissive mouse vocalizes the least and is defeated more often in the tube test. An examination of social hierarchy in SGH mice compared with MGH mice revealed a linear correlation between tube test and courtship rankings for mice in 
SGH but not for mice in MGH (Fig. 2C). In particular, all mice from SGH that won in the tube test were the ones vocalizing the most (SGH 1 and MGH 1.92, $P=0.033$; Fig. 2D), indicating a clear social hierarchy. However, only $38 \%$ of the mice from MGH that won the tube test were the ones that vocalized the most (Fig. 2D), revealing that a structured social hierarchy had not developed in mice from MGH.

Because of this defect in the development of a social hierarchy in mice from MGH, we compared their territorial and courtship behavior with that of $N \operatorname{lgn} 3^{y /+}$ mice from $\mathrm{SGH}$. In the tube test, unfamiliar submissive male mice more frequently defeated $N \operatorname{lgn} 3^{y /-}$ mice from $\mathrm{MGH}$ than $\mathrm{Nlgn}^{\mathrm{y} /+}$ and $\mathrm{Nlgn}^{\mathrm{y} /-}$ mice from SGH $\left(\mathrm{Nlgn}^{\mathrm{y} /+} \mathrm{SGH}\right.$ $57.9 \% \pm 7.9 \%, \mathrm{Nlgn}^{y /-} \mathrm{SGH} 76.2 \% \pm 6.1 \%, \mathrm{Nlgn}^{\mathrm{y} /+}$ $\mathrm{MGH} 38.1 \% \pm 10.4 \%$, and $\mathrm{Nlgn}^{\mathrm{y} /-} \mathrm{MGH} 18.5 \% \pm$ $12.6 \%, P=0.023$; Fig. $3 A$ ). Levels of testosterone, a marker of social dominance (Juntti et al., 2010), were also reduced in the urine of $\mathrm{Nlgn}^{\mathrm{y} /-}$ and $\mathrm{Nlgn}^{\mathrm{y} / \mathrm{+}}$ mice from MGH compared with those of $\mathrm{Nlgn}^{\mathrm{y} / \mathrm{f}}$ mice from SGH and unexpectedly not different from levels found in the urine of $\mathrm{Nlgn}^{+/+}$mice $\left[\mathrm{Nlgn} 3^{\mathrm{y} /+} \mathrm{SGH} 39,223 \pm 4106\right.$ $\mu \mathrm{g} / \mathrm{ml}, \mathrm{Nlgn}^{y /+} \mathrm{MGH} 15,738 \pm 3687 \mu \mathrm{g} / \mathrm{ml}$, Nlgn3 $3^{y /-}$ $\mathrm{MGH} 16,736 \pm 3779 \mu \mathrm{g} / \mathrm{ml}$, and $\mathrm{Nlgn}^{+/+} 17,182 \pm 3160$ $\mu \mathrm{g} / \mathrm{ml}$, main effect $P<0,0001, F_{(3,32)}=9.85$; Fig. $\left.3 B\right]$. The time spent calling a female in estrus was similar between $\mathrm{Nlgn}^{y /+}$ mice from SGH and MGH and increased compared with $\mathrm{Nlgn}^{y /-}$ mice from SGH and MGH $\left[\mathrm{Nlgn} 3^{y /+}\right.$ SGH $13.6 \pm 2.7 \mathrm{~s}, \mathrm{Nlgn}^{y /-} \mathrm{SGH} 6.38 \pm 3.2 \mathrm{~s}$, Nlgn3 ${ }^{y /+}$ MGH $22.2 \pm 3.5 \mathrm{~s}$, and N/gn3 ${ }^{y /-} \mathrm{MGH} 9.8 \pm 2.8 \mathrm{~s}$; main effect, $P=0.014, F_{(2,52)}=4.62$; Fig. $\left.3 C\right]$. Note that the expression level of Cyp2d9, a marker of sexual dimorphism in the liver, was not affected by housing (N/gn3 $3^{y /+}$ SGH $1 \pm 0.08, \mathrm{Nlgn}^{y /-} \mathrm{SGH} 0.88 \pm 0.21, \mathrm{Nlgn}^{y /+} \mathrm{MGH}$ $0.89 \pm 0.21$, and $\mathrm{Nlgn} 3^{y /-} \mathrm{MGH} 1.07 \pm 0.09$; Fig. $3 D$ ), indicating a similar degree of sexual maturation between the different groups of mice. These results demonstrate that social housing modifies the competitive behavior of $\mathrm{N} / g n 3^{y /-}$ mice without affecting their courtship behavior.

Because social hierarchy is affected in litters from $\mathrm{MGH}$, we speculated that the social behavior of $\mathrm{Nlgn} 3^{y /+}$ and $\mathrm{Nlgn} 3^{y /-}$ mice from MGH would also be affected, and therefore investigated their interest for social odors. Whereas $\mathrm{Nlgn}^{y /+}$ mice from SGH spent more time investigating social cues compared with water or banana odors, $\mathrm{Nlgn}^{\mathrm{y} / \mathrm{t}}$ mice from MGH spent a similar amount of time investigating social and nonsocial cues, showing an absence of interest for social cues [N/gn $3^{y /+} \mathrm{SGH}$ : water $1.9 \pm 0.6 \mathrm{~s}$, banana $3.1 \pm 1.1 \mathrm{~s}$, social $20.6 \pm 2.6 \mathrm{~s}$; $\mathrm{Nlgn}^{\mathrm{y} /-} \mathrm{SGH}$ : water $1.4 \pm 0.2 \mathrm{~s}$, banana $4.0 \pm 0.9 \mathrm{~s}$, social $17.8 \pm 1.9 \mathrm{~s} ; \mathrm{Nlgn}^{\mathrm{y} /+} \mathrm{MGH}$ : water $2.6 \pm 1 \mathrm{~s}$, banana $2.8 \pm 5.2 \mathrm{~s}$, social $3 \pm 2 \mathrm{~s}$; Nlgn $3^{y /-} \mathrm{MGH}$ : water $0.7 \pm 0.5 \mathrm{~s}$, banana $2 \pm 1.3 \mathrm{~s}$, social $8.96 \pm 1.9 \mathrm{~s}$; main effect of odor, $P=0.0001, F_{(2,82)}=57.7$; main effect of genotype, $P=0.0006, F_{(3,41)}=7.0$; interaction odor $\times$ genotype, $P<0.0001, F_{(6,82)}=9.7$; Fig. $\left.4 A\right]$. In addition, $\mathrm{Nlgn}^{y /+}$ mice from MGH spent a similar amount of time exploring social odors and control presented simultaneously, showing that their social discrimination was also affected $\left[N / g n 3^{y /+} \mathrm{MGH}\right.$ : social $7 \pm 0.7 \mathrm{~s}$, control $8 \pm 1.2$ $\mathrm{s} ; \mathrm{Nlgn} 3^{y /-} \mathrm{MGH}$ : social $8 \pm 0.8 \mathrm{~s}$, control $6 \pm 0.6 \mathrm{~s}$; $\mathrm{Nlgn}^{\mathrm{y/+}+} \mathrm{Pval}^{\mathrm{Cre} /+}$ : social $18 \pm 6.4 \mathrm{~s}$, control $6.3 \pm 1.7 \mathrm{~s}$; $\mathrm{Nlgn}^{\mathrm{y} /-}{ }^{-} \mathrm{Pvalb}^{\mathrm{Cre} /+}$ : social $17.4 \pm 3.6 \mathrm{~s}$, control $9.1 \pm 2.5$ $\mathrm{s}$; main effect of odor, $P<0.0001, F_{(1110)}=15.6$; main effect of genotype, $P<0.0001, F_{(3110)}=10.7$; interaction Pvalb $\times$ odor, $P<0.0001, F_{(1.114)}=31.9$; Fig. $\left.4 B\right]$. Although $\mathrm{Nlgn}^{\mathrm{y} /-}$ mice from SGH and $\mathrm{NIgn} 3^{y /-}$ from $\mathrm{MGH}$ spent more time investigating social cues, $N \operatorname{lgn} 3^{y /-}$ mice from SGH spent more time investigating the social odor than $\mathrm{Nlgn}^{\mathrm{y} /-}$ mice from $\mathrm{MGH}$. Note that $\mathrm{Nlgn}^{\mathrm{y} /-}$ mice from MGH showed more interest in social odor than banana (Fig. $4 A$ ) but failed to show a preference for social odors versus control (Fig. 4B). This is most likely due to differences in protocol: Fig. $4 A$ measures the interest for odors and Fig. $4 B$ the ability to discriminate between social and nonsocial cues (see Materials and Methods). These results indicate that MGH affects the interest in social odors of $\mathrm{Nlgn} 3^{y /+}$ and $\mathrm{Nlgn} 3^{y /-}$ mice.

To investigate the causal role of $\mathrm{Nlgn}^{y /-}$ mouse behavior in that of their littermates, we re-expressed Nlgn3 in parvalbumin (Pvalb)-expressing interneurons, known to regulate social behavior in mice (Belforte et al., 2010; Del Pino et al., 2013; Saunders et al., 2013; Billingslea et al., 2014; Ito-Ishida et al., 2015; Wöhr et al., 2015; Zou et al., 2016). After Nlgn3 re-expression in Pvalb-expressing interneurons, we detected Neuroligin-3 in several parts of the brain, including cerebellum (ratio $N \operatorname{lgn} 3^{y /-} \mathrm{Pvall}^{\mathrm{Cre} /+}$ to $\left.\mathrm{Nlgn}^{\mathrm{y} / \mathrm{+}}: \sim 0.7\right)$, brainstem $(\sim 0.15)$, striatum $(\sim 0.1)$, thalamus $(\sim 0.1)$, and cortex $(\sim 0.04)$ and failed to detect it in the hippocampus (Fig. 4C). Re-expression of N/gn3 in $P$ valb-expressing interneurons was sufficient to increase the time $\mathrm{Nlgn}^{\mathrm{y/} /}$ Pvalb $\mathrm{Cre}^{++}$and $\mathrm{Nlgn}^{\mathrm{y/t}+} \mathrm{Pval} \mathrm{b}^{\mathrm{Cre} /+}$ mice spent investigating social odors compared with controls (Fig. 4B). In addition, we found that $N / g n 3^{y /-} \mathrm{Pvalb}^{\mathrm{Cre} /+}$ mice won as frequently against submissive wild-type mice but vocalized less than $\mathrm{Nlgn}^{\mathrm{y} /+} \mathrm{Pvalb}^{\mathrm{Cre} /+}$ mice $\left(\mathrm{Nlgn}^{\mathrm{y} /+}\right.$ Pvalb ${ }^{\text {Cre/+ }} 62.9 \% \pm 11.7 \%, \mathrm{Nlgn}^{\mathrm{y} /-} \mathrm{Pval}^{\mathrm{Cre} /+} 62.5 \% \pm$

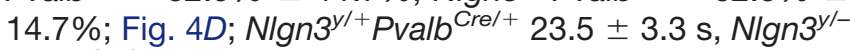
Pvalb ${ }^{\text {Cre/ }+} 8.4 \pm 5.2 \mathrm{~s} ; P=0.01$; Fig. $4 E$ ), indicating that Nlgn3 in Pvalb-expressing interneurons controls the territorial behavior but not courtship behavior in individual mice. To determine whether re-expression of Nlgn3 in Pvalb-expressing cells affects social interaction in $\mathrm{Nlgn}^{\mathrm{y/-}}$ and $\mathrm{Nlgn} 3^{\mathrm{y/+}}$ mice, we exposed mice at P21-P28 to an unfamiliar adult female mouse and measured the amount of time they spent interacting. N/gn $3^{y /-}$ mice and their $\mathrm{Nlgn} 3^{y /+}$ littermates spent less time in social interaction than $\mathrm{Nlgn}^{\mathrm{y/t}}$ and $\mathrm{Nlgn} 3^{\mathrm{y} /-}$ mice from SGH or $\mathrm{Nlgn}^{\mathrm{y} /-} \mathrm{Pvalb} \mathrm{Cre}^{\mathrm{Cr}+}$ and $\mathrm{Nlgn} 3^{\mathrm{y} /+} \mathrm{Pvalb}{ }^{\mathrm{Cre} /+}$ mice $\left[\mathrm{Nlgn}^{\mathrm{y} /+}\right.$ $\mathrm{SGH} 142.6 \pm 6.8 \mathrm{~s}, \mathrm{Nlgn}^{\mathrm{y} /-} \mathrm{SGH} 136.6 \pm 6.6 \mathrm{~s}, \mathrm{Nlgn}^{\mathrm{y} /+}$ MGH $110.3 \pm 4.4 \mathrm{~s}, \mathrm{Nlgn}^{\mathrm{y} /-} \mathrm{MGH} 111 \pm 10.2 \mathrm{~s}, \mathrm{Nlgn}^{\mathrm{y} /-}$ Pvalb $^{\text {Cre/+ }} 131.1 \pm 7 \mathrm{~s}$, Nlgn $^{\text {y/+ }}$ Pvalb $^{\text {Cre/+ }} 142 \pm 5.6 \mathrm{~s}$; main effect of housing $P<0.0001, F_{(2,65)}=11.4 ; P<$ 0.001 in Fig. 5A], indicating that re-expression of Nlgn3 in $P$ valb-expressing cells rescues the interest in social interaction of $\mathrm{Nlgn} 3^{y /-}$ and $\mathrm{Nlgn} 3^{y /+}$ mice to levels similar to those of mice from SGH. Independently of the housing and re-expression in Pvalb-expressing interneurons, $N \operatorname{lgn} 3^{y /-}$ mice traveled greater total distance in the OF than $\mathrm{Nlgn}^{\mathrm{y} /+}$ mice $\left[\mathrm{Nlgn}^{\mathrm{y} /+} \mathrm{SGH} 3977 \pm 189 \mathrm{~cm}\right.$, 
$N^{\prime g n} 3^{y /-}$ SGH $4753 \pm 202 \mathrm{~cm}$, Nlgn $^{y /+}$ MGH $3796 \pm 186$ $\mathrm{cm}, \mathrm{Nlgn}^{\mathrm{y} /-} \mathrm{MGH} 5299 \pm 426 \mathrm{~cm}, \mathrm{Nlgn} 3^{\mathrm{y} /-} \mathrm{Pvalb}^{\mathrm{Cre} /+}$ $3683 \pm 314 \mathrm{~cm}$, Nlgn $^{y /+}{ }^{y v a l b^{C r e /+}} 4856 \pm 363 \mathrm{~cm}$; main effect of genotype $P=0.0018, F_{(1,69)}=10.49$; Fig. $\left.5 B\right]$. Mice from all genotype and housing groups traveled a similar normalized distance in the center of the OF $\left(\mathrm{Nlgn3}^{\mathrm{y} /+} \mathrm{SGH} 0.32 \pm 0.02 \mathrm{~cm}, \mathrm{Nlgn}^{\mathrm{y} /-} \mathrm{SGH} 0.29 \pm 0.01\right.$ $\mathrm{cm}, \mathrm{Nlgn}^{\mathrm{y} /+} \mathrm{MGH} 0.29 \pm 0.01 \mathrm{~cm}, \mathrm{Nlgn}^{y /-} \mathrm{MGH}$ $0.29 \pm 0.01 \mathrm{~cm}, \mathrm{Nlgn}^{\mathrm{y} /-}{ }^{-} \mathrm{Pvalb} \mathrm{bre}^{\mathrm{Cr}+} 0.25 \pm 0.02 \mathrm{~cm}$, Nlgn $3^{y /+} P$ valb ${ }^{\text {Cre } /+} 0.31 \pm 0.02 \mathrm{~cm}$; Fig. $5 C$ ). Mice from all genotype and housing groups spent similar amounts of time in the open arms of the EPM $\left(\mathrm{Nlgn}^{\mathrm{y} /+} \mathrm{SGH} 71.3 \pm\right.$ $7.5 \mathrm{~s}, \mathrm{Nlgn}^{y /-} \mathrm{SGH} 87.26 \pm 9.0 \mathrm{~s}, \mathrm{Nlgn}^{\mathrm{y} /+} \mathrm{MGH} 89.6 \pm$ $9.6 \mathrm{~s}, \mathrm{Nlgn}^{\mathrm{y} /-} \mathrm{MGH} 110.5 \pm 9.6 \mathrm{~s}, \mathrm{Nlgn}^{\mathrm{y} /-} \mathrm{Pvalb}^{\mathrm{Cre} /+}$ $95.9 \pm 12.1 \mathrm{~s}, \mathrm{Nlgn}^{\mathrm{y} /+} \mathrm{Pvalb}^{\mathrm{Cre} /+} 100.4 \pm 12.2 \mathrm{~s}$; Fig. $5 D$ ). These results show that $\mathrm{N} / g n 3^{y /-}$ and $N / g n 3^{y /+}$ mice from $\mathrm{MGH}$ are not more anxious than mice from SGH. Note that there are no significant differences between the behavior of $\mathrm{Nlgn}^{\mathrm{y/t}}$ mice from SGH or MGH and $\mathrm{Nlgn}^{\mathrm{y/t}} \mathrm{Pval}^{\mathrm{Cre} /+}$ mice (Fig. 4D, $E$ and Fig. 5A-D). This indicates that, consistent with previous reports, the expression of Cre recombinase in parvalbumin-expressing neurons of wildtype animals is not sufficient to produce a phenotype in wild-type male mice (Hippenmeyer et al., 2005). In contrast to $\mathrm{Nlgn} 3^{y /-}$ mice, female mice from MGH lacking Nlgn3 $\left(\mathrm{Nlgn3}^{-/}\right)$spent a similar amount of time in social contact with $\mathrm{Nlgn}^{-1-}$ mice from SGH (SGH $120 \pm 6.6 \mathrm{~s}$ and MGH $117.5 \pm 9.4 \mathrm{~s}$; Fig. $5 E$ ). $\mathrm{Nlgn}^{-/-}$mice from MGH and from SGH traveled a similar distance in the OF (SGH $6098 \pm 379 \mathrm{~cm}$ and MGH $5253 \pm 338 \mathrm{~cm}$; Fig. 5F), similar normalized distance in the center of the OF (SGH $0.27 \pm$ $0.01 \mathrm{~cm}$ and MGH $0.29 \pm 0.02 \mathrm{~cm}$; Fig. $5 G$ ), and similar amounts of time in the open arms of the EPM (SGH $87.3 \pm$ $9.0 \mathrm{~s}$ and MGH $113 \pm 9.0 \mathrm{~s}$; Fig. $5 H$ ). These results demonstrate that MGH modifies the social behavior of $\mathrm{Nlgn}^{\mathrm{y/t}}$ and $\mathrm{Nlgn}^{\mathrm{y} /-}$ mice but not that of $\mathrm{Nlgn}^{-/-}$mice. Moreover, re-expression of Nlgn3 in Pvalb-expressing interneurons restores social behavior in $N \operatorname{lgn} 3^{y /-}$ mice and their wild-type littermates to levels found in mice from $\mathrm{SGH}$, demonstrating that $\mathrm{NIgn} 3^{\mathrm{y} /-}$ mice modify the social behavior of their littermates.

The social submission of $\mathrm{Nlgn} 3^{y /-}$ mice could modify their anxiety, so we next examined the effect of social housing conditions on stress related to a novel environment and to burying behavior. To investigate this anxiety, we analyzed the behavior of mice from litters consisting of both genotypes (MGH), in comparison with litters in which male mice were all of the same genotype, $\mathrm{Nlgn}^{\mathrm{y} /+}$ or $\mathrm{Nlgn3}^{y /-}$ (SGH). Radyushkin et al. (2009) showed that $\mathrm{Nlgn}^{\mathrm{y} / \mathrm{-}}$ mice are hyperactive and less stressed than their $\mathrm{Nlgn}^{\mathrm{y} /+}$ littermates. Importantly, $\mathrm{Nlgn} 3^{y /-}$ mice showed increased activity in the OF, increased exploration of the hole board, and decreased burying behavior but not change in the exploration of the EPM, indicating that only certain aspects of their anxiety were affected (Radyushkin et al., 2009). Consistently, we found that $\mathrm{Nlgn}^{\mathrm{y} /-}$ mice from MGH traveled further in the OF compared with $\mathrm{Nlgn}^{\mathrm{y} /+}$ mice from MGH $\left[\mathrm{Nlgn} 3^{\mathrm{y} /+} \mathrm{SGH} 3373 \pm 323 \mathrm{~cm}\right.$, $N^{\prime g n} 3^{y /-}$ SGH $3186 \pm 324 \mathrm{~cm}, \mathrm{Nlgn}^{\mathrm{y} /+} \mathrm{MGH} 3521 \pm 151$ $\mathrm{cm}$, and N/gn3 $3^{y /-}$ MGH $4684 \pm 285 \mathrm{~cm}$; main effect of housing $P=0.004, F_{(1,75)}=8.82$; interaction housing $\times$ genotype $P=0.017, F_{(1,75)}=5.94$; Fig. $\left.6 A\right]$. Although housing condition had no effect on $N \operatorname{lgn} 3^{y /+}$ mice, $\mathrm{Nlgn}^{y /-}$ mice from MGH traveled an increased distance in comparison to $\mathrm{Nlgn} 3^{y /-}$ from SGH (Fig. 6A). However, spontaneous activity (number of beam break) over $30 \mathrm{~h}$ $\left(N_{\operatorname{lgn} 3}{ }^{y /+}\right.$ SGH $9322 \pm 1090$, Nlgn3 $^{y /-}$ SGH 10,979 \pm 703 , $\mathrm{Nlgn}^{y /+}$ MGH 10,357 \pm 1648 and N/gn3 $3^{y /-}$ MGH 11,005 \pm 933; Fig. 6B) and increased nocturnal activity (Fig. 6C) did not differ from any other group tested. Increased velocity in an OF can be triggered by an increased motoric drive and by emotional reactivity to the novelty of the environment. The time spent by the wall of the open field (thigmotaxis) is a measure of this anxiety. To correct for the differing distances traveled between groups, we normalized the distance traveled in the center to the total distance traveled by the mice in the OF. N/gn $3^{y /-}$ mice from SGH showed decreased thigmotaxis compared with $\mathrm{Nlgn}^{y /-}$ from $\mathrm{MGH}$, whereas housing condition had no effect on the thigmotaxis (ratio distance in the center/total distance) of $\mathrm{Nlgn}^{\mathrm{y} / \mathrm{t}}$ mice $\left[\mathrm{Nlgn} 3^{y /+} \mathrm{SGH} 0.19 \pm 0.01\right.$, $\mathrm{Nlgn}^{y /-}$ SGH $0.37 \pm 0.04, \mathrm{Nlgn}^{y /+} \mathrm{MGH} 0.26 \pm 0.01$, and $\mathrm{Nlgn}{ }^{y /-} \mathrm{MGH} 0.28 \pm 0.02$; main effect of genotype $P$ $<0.0001, F_{(1,72)}=22.35$; interaction genotype $\times$ housing $P<0.0001, F_{(1,72)}=17.29$; Fig. $6 D$ ]. In addition, we found that mice from MGH buried more marbles than mice from $\mathrm{SGH}\left[\mathrm{Nlgn} 3^{y /+} \mathrm{SGH} 12.6 \pm 1.2, \mathrm{Nlgn}^{y /-} \mathrm{SGH} 7.6 \pm 1.4\right.$, $\mathrm{Nlgn}^{\mathrm{y} / \mathrm{+}} \mathrm{MGH} 14.6 \pm 3.9$, and $\mathrm{Nlgn} 3^{\mathrm{y} /-} \mathrm{MGH} 11.4 \pm 1.2$; main effect of housing $P=0.0407, F_{(1,43)}=4.45$; main effect of genotype $P=0.0044, F_{(1,43)}=9.06$; Fig. $6 E$. Increased numbers of buried marbles can be a result of increased anxiety or increased repetitive behavior (Deacon, 2006). Therefore, these results show that mixed genotype housing increases anxiety or compulsive behavior in adult $N \operatorname{lgn} 3^{y /-}$ and, to a lesser extent, $N \operatorname{lgn} 3^{y /+}$ mice. These results also show that $N \operatorname{lgn} 3^{y /-}$ mice are more reactive to novelty when raised in MGH compared with $\mathrm{SGH}$, indicating that anxiety related to novelty is increased in these mice when raised with wild-type littermates.

We then investigated whether females lacking Nlgn3 would show behavior similar to that of $N / g n 3^{y /-}$ mice and, in particular, influence the behavior of their littermates. Because Nlgn3 is an X-linked gene, we could not naturally obtain littermate cages containing $\mathrm{Nlgn}^{-/-}$and $\mathrm{Nlgn}^{+/+}$ mice. Therefore, we investigated the effect of $\mathrm{Nlgn}^{-/-}$or $\mathrm{Nlgn}^{+/+}$mouse behavior on that of $\mathrm{Nlgn}^{+/-}$littermates. We found that $\mathrm{Nlgn}^{+/-}$mice raised with $\mathrm{Nlgn}^{+/+}$littermates were indistinguishable from $\mathrm{Nlgn}^{+/+}$mice in the time spent in contact with an unfamiliar female $\left[\mathrm{Nlgn3^{+/+ }}\right.$ $99.8 \pm 8.36 \mathrm{~s}, \mathrm{Nlgni}^{+/-} \mathrm{WT}_{\mathrm{WT}} 114.1 \pm 6 \mathrm{~s}, \mathrm{Nlgn3}^{+/-} \mathrm{KO} 68 \pm$ $3.8 \mathrm{~s}, \mathrm{Nlgn3}^{-1-} 65.8 \pm 6.3 \mathrm{~s}, \mathrm{P}<0.0001, F_{(3,33)}=12.5$; Fig. $7 A]$, distance traveled in the OF $\left[\mathrm{Nlgn3}^{+/+} 4515 \pm 321\right.$

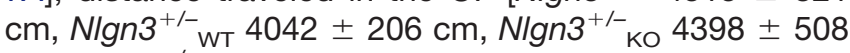
$\mathrm{cm}, \mathrm{Nlgn3}^{-/} 5870 \pm 274 \mathrm{~cm}, \mathrm{P}=0.0011$; Fig. 7B], thigmotaxis $\left[\mathrm{Nlgn}^{+/+} 0.23 \pm 0.02, \mathrm{Nlgn3}^{+/-}\right.$WT $0.25 \pm$ $0.01, \mathrm{Nlgn}^{+/-}$KO $0.24 \pm 0.02, \mathrm{Nlgn}^{-/-} 0.31 \pm 0.01, \mathrm{P}=$ $0.0009, F_{(3,45)}=6.5$; Fig. $7 C$ ], and time spent in the open arm of the EPM $\left(\mathrm{Nlgn3}^{+/+} 130.4 \pm 7.1 \mathrm{~s}, \mathrm{Nlgn3}^{+/-}{ }_{\text {WT }}\right.$ $109.3 \pm 8.8 \mathrm{~s}, \mathrm{Nlgn3}^{+/-}$Ko $127.6 \pm 9.1 \mathrm{~s}, \mathrm{Nlgn}^{-/-} 124 \pm$ 

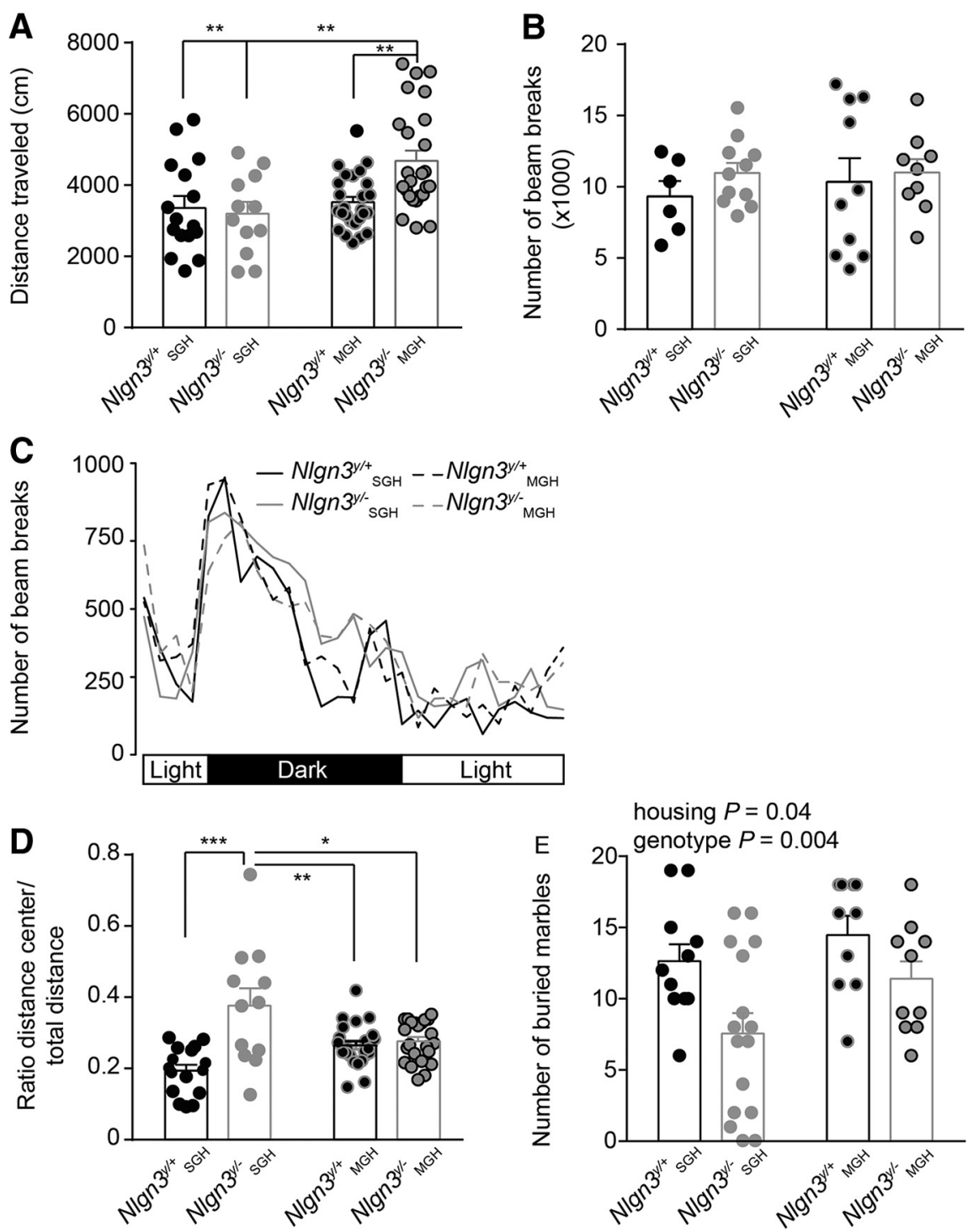

Figure 6. Increased anxiety in adult (2- to 4-mo-old) $\mathrm{Nlgn}^{y /-}$ mice from $\mathrm{MGH}$. $\boldsymbol{A}$, Increased distance traveled in OF in $\mathrm{Nlgn} 3^{y /-}$ mice from MGH compared to $\mathrm{Nlgn} 3^{y /-}$ mice in SGH and $\mathrm{Nlgn}^{y /+}$. B, No change in the average number of beam breaks per hour recorded over 30 h. $\boldsymbol{C}$, Number of beam breaks per hour over 30 h. $\boldsymbol{D}$, Increased normalized distance traveled in the center of the OF for Nlgn3 ${ }^{y /-}$ mice in SGH compared with $\mathrm{Nlgn}^{\mathrm{y} /+}$ mice from SGH and mice from $\mathrm{MGH}$. $\boldsymbol{E}$, Increased number of marbles buried by mice in $\mathrm{MGH}$ compared with mice from SGH. NIgn3 $3^{y /-}$ mice in SGH buried fewer marbles than $N / g n 3^{y /+}$ mice in SGH. Values are represented as mean \pm SEM. Statistical significance was tested by two-way ANOVA and post hoc Sidak's multiple comparison test. $* P<0.05$; $* * P<0.01 ; * * * P<0.001(\boldsymbol{A}, \boldsymbol{B}, \boldsymbol{D}$, and $\boldsymbol{E})$.

$13.3 \mathrm{~s} ;$ Fig. 7D). However, $\mathrm{Nlgn}^{-/-}$mice showed less time spent in contact with an unfamiliar female, decreased thigmotaxis, and similar amount of time in the open arms of the EPM compared with $\mathrm{Nlgn}^{+/+}$mice (Fig. 7A-D), showing that the behavior of adult $\mathrm{Nlgn3}^{-/}$mice phenocopies that of adult $\mathrm{Nlgn}^{\mathrm{y} /-}$ mice. Interestingly, $\mathrm{Nlgn}^{+/-}$ mice raised with $\mathrm{Nlgn3}^{-/-}$mice spent less time in contact with an unfamiliar female than $\mathrm{Nlgn}^{+/-}$mice raised with $\mathrm{Nlgn}^{+/+}$littermates (Fig. 7A), indicating that, like males, female $\mathrm{Nlgn}^{-1-}$ mice modify the behavior of their littermates. Note that in measures of anxiety, the $\mathrm{Nlgn}^{+/-}$ mice raised with $\mathrm{Nlgn}^{-/-}$mice were indistinguishable from $\mathrm{Nlgn}^{+/-}$mice raised with $\mathrm{Nlgn}^{+/+}$littermates (Fig. $7 B-D$ ), suggesting that the behavior of $\mathrm{Nlgn}^{-/-}$mice does not affect the anxiety of their littermates. These results demonstrate that the behavior of adult $\mathrm{Nlgn}^{-/-}$mice phenocopies that of $\mathrm{Nlgn}^{\mathrm{y} /-}$ adult mice and that $\mathrm{Nlgn}^{-{ }^{-1}}$ mice have a different influence on the social behavior of their littermates than $\mathrm{Nlgn}^{+/+}$mice.

\section{Discussion}

Taken together, the results of these experiments reveal an unexpected impact of the Nlgn3 deletion on social behavior in male and female mouse littermates. First, we showed that young and adult male $N \operatorname{lgn} 3^{y /+}$ and $N \operatorname{lgn} 3^{y /-}$ mice modify each other's social behavior. In addition, our results indicate that $\mathrm{MGH}$ increases adult $\mathrm{Nlgn}^{\mathrm{y} /-}$ mouse anxiety, related to novel environment but not to height, 

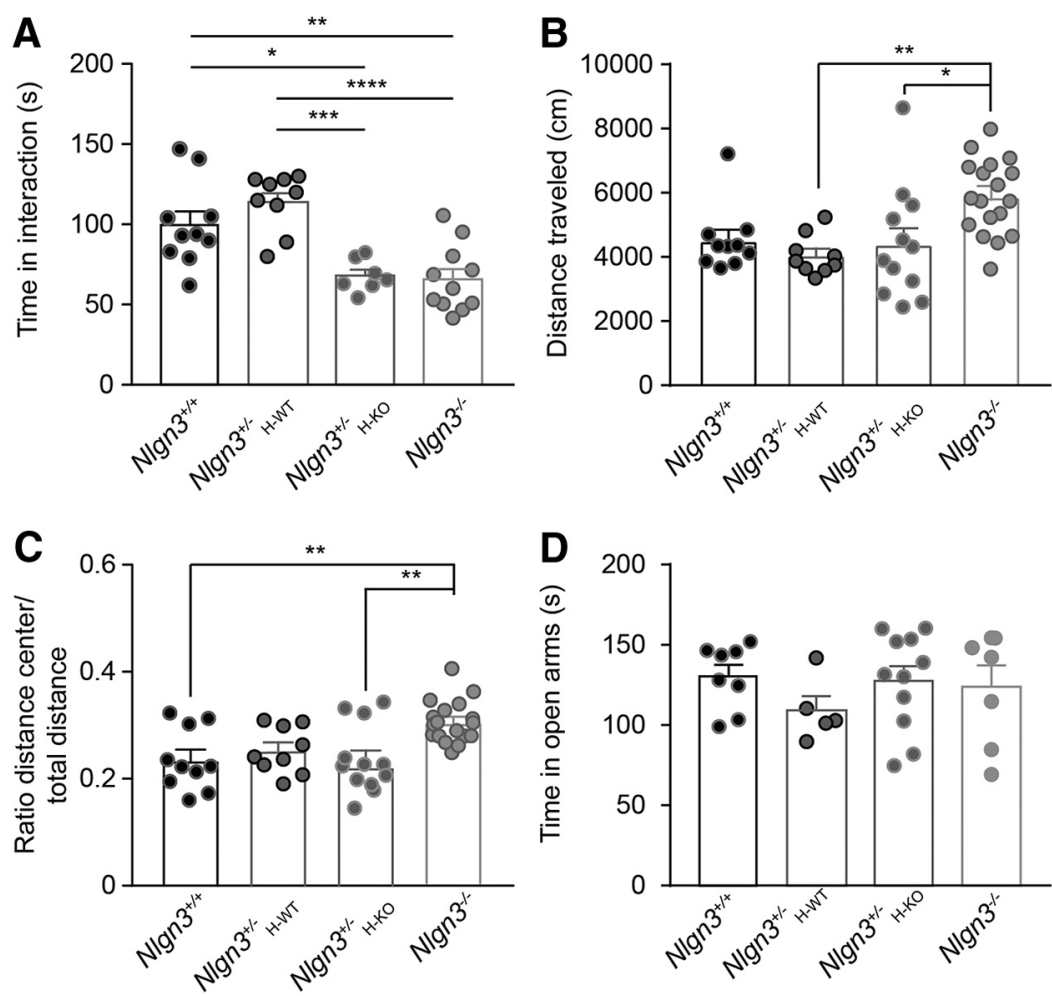

Figure 7. Adult (2- to 4-mo-old) $\mathrm{Nlgn}^{-/-}$mice modify the social behavior of their littermates. We analyzed two littermate groups in which (1) $\mathrm{Nlgn}^{+/-}$mice $\left(\mathrm{Nlgn}^{+/-}{ }_{\mathrm{H}-\mathrm{WT}}\right)$ were littermates of $\mathrm{Nlgn}^{+/+}$mice or (2) $\mathrm{Nlgn}^{+/-}$mice $\left(\mathrm{Nlgn} 3^{+/-} \mathrm{H}-\mathrm{KO}\right)$ were littermates of

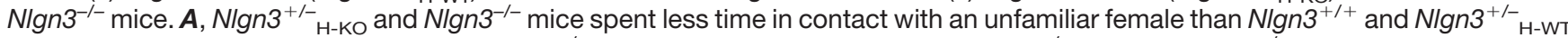
mice. $\boldsymbol{B}$, Increased distance traveled by $\mathrm{Nlgn}^{-/-}$mice in the OF compared with $\mathrm{Nlgn}^{+/-} \mathrm{H}-\mathrm{WT}$ and $\mathrm{Nlgn}^{+/-} \mathrm{H}-\mathrm{KO}$ mice. $\mathrm{C}$, Increased normalized distance traveled in the center of the OF for $\mathrm{Nlgn}^{-/-}$mice. $\boldsymbol{D}$, No change in the time spent in the open arms of the EPM. Values are represented as mean \pm SEM. Statistical significance was tested by one-way ANOVA and post hoc Tukey's multiple comparison test $(\boldsymbol{A}, \boldsymbol{C}$, and $\boldsymbol{D})$ and Kruskal-Wallis and post hoc Dunn's multiple comparison tests $(\boldsymbol{B})$. $* P<0.05 ; * * P<0.001$; $* * * P<0.001 ; * * * P<0.0001$

and potentially increases their compulsive behavior. This result is consistent with a previous report showing that the lack of Nlgn3 affects only specific aspects of anxiety in mice (Radyushkin et al., 2009). Importantly, we found that re-expression of Nlgn3 in Pvalb-expressing interneurons was sufficient to normalize the behavior of $N \operatorname{lgn} 3^{y /-}$ mice and restore normal social behavior in their wild-type littermates, demonstrating that $N / g n 3^{y /-}$ mice are causing this phenotype in their $\mathrm{Nlgn} 3^{\mathrm{y} /+}$ littermates. Finally, although the behavior of $\mathrm{Nlgn3}^{-/-}$mice is not modified by the social environment, we observed that housing with $\mathrm{Nlgn}^{+/+}$or $\mathrm{Nlgn}^{-/-}$mice promotes different interests in social behavior in $\mathrm{Nlgn}^{+/-}$mice.

Using $\mathrm{Nlgn} 3^{y /-}$ Pvalb ${ }^{\text {Cre/+ }}$ mice, we were able to demonstrate a causal link between the behavioral phenotype of $N \operatorname{lgn} 3^{y /-}$ mice and that of their littermates. Some evidence confirms that the phenotype of $\mathrm{Nlgn}^{\mathrm{y} /+}$ mice in MGH cannot be due to mothering or early life events. First, all dams of $\mathrm{Nlgn}^{\mathrm{y/+}}, \mathrm{Nlgn}^{\mathrm{y/L}}, \mathrm{Nlgn}^{\mathrm{y/+}} \mathrm{Pvalb}^{\mathrm{Cre} /+}$, and $\mathrm{Nlgn} 3^{\mathrm{y} /-} \mathrm{Pval} \mathrm{b}^{\mathrm{Cre} /+}$ mice were of the same $\mathrm{Nlgn} 3^{+/-}$ genotype. We found that the maternal behavior of these $\mathrm{Nlgn3}^{+/-}$dams is comparable to that of $\mathrm{Nlgn}^{+/+}$mice (data not shown), consistent with an absence of mothering effect. Second, activation of the Pvalb promoter in the brain occurs around P14 (http://developingmouse.brainmap.org); therefore, the interference of behavior between
$N \operatorname{lgn} 3^{y /+}$ mice and their $N \operatorname{lgn} 3^{y /-}$ littermates is unlikely to be due to prenatal events. Third, transfer of anxiety or fear (Langford et al., 2006; Smith et al., 2016) could explain the phenotype observed in $\mathrm{Nlgn}^{y /+}$ mice in MGH. However, we did not find any increased anxiety in young animals or adult female mice, showing that the defective social behavior observed in $\mathrm{Nlgn} \mathrm{y}^{\mathrm{y}+}$ mice from MGH is not due to social anxiety as a result of MGH. Finally, re-expression of Nlgn3 in parvalbumin-expressing cells restores the social behavior of $\mathrm{Nlgn} 3^{y /-}$ mice and that of their $\mathrm{Nlgn} 3^{y /+}$ littermates without affecting the hyperactivity of $\mathrm{Nlgn}^{\mathrm{y} /-}$ mice. This result suggests that it is not the hyperactivity of $N / g n 3^{y /-}$ mice that causes the social phenotype in $\mathrm{NIgn}^{\mathrm{y} /+}$ mice but rather their social behavior deficits.

The finding that Nlgn3 in parvalbumin cells controls social behavior is consistent with studies showing that mice lacking parvalbumin display deficits in social behavior (Wöhr et al., 2015). Loss of parvalbumin also leads to defects in excitation and inhibition (E/I) balance, a common pathologic feature in mouse models of ASD (Lee et al., 2017). Results show that the phenotype of $\mathrm{Nlgn}^{y /-}$ mice is also underlined by a deficit in E/I balance caused by a decrease in inhibitory but not excitatory postsynaptic currents in the striatum (Rothwell et al., 2014). Re-expression of Nlgn3 in parvalbumin-expressing interneurons is therefore likely to be sufficient to restore inhibitory postsynaptic currents and E/I 
balance in neuronal circuits, rescuing some aspect of the $\mathrm{Nlgn}^{\mathrm{y} /-}$ mouse phenotype. Theories on the pathophysiology of ASD have hypothesized that some of the symptoms associated with ASD may be caused by an E/l imbalance in the cortex or the striatum (Rapanelli et al., 2017). In Nlgn $3^{y /-}$ $P$ valb $b^{\text {Cre/+ }}$ mice, restoration of the $\mathrm{E} / \mathrm{l}$ balance is more likely to occur in the striatum, where we detected re-expression of Nlgn3, rather than in the cortex, where we detected low levels of re-expression, close to background. We also detected a high level of re-expression of Nlgn3 in the cerebellum, a brain region associated with the $N \operatorname{lgn} 3^{y /-}$ mouse phenotype (Baudouin, 2014), ASD-associated phenotypes in mice (Tsai et al., 2012), and symptoms of ASD in humans (Wang et al., 2014). The alleviation of the phenotype in $\mathrm{Nlgn}^{\mathrm{y} /-}$ mice could therefore arise from a restoration of neuronal network activity in the striatum or cerebellum.

Our results also show similarities in phenotypes of male and female mice lacking Nlgn3. Indeed, like the N/gn $3^{y /-}$ mice studied here and in Radyushkin et al. (2009), $\mathrm{Nlgn}^{-/-}$mice show increased activity in the OF and spend similar amounts of time in the open arms of the EPM compared with wild-type mice. Unlike $\mathrm{Nlgn}^{-/-}$mice, $\mathrm{Nlgn3}^{+/-}$mice show behavior similar to that of their $\mathrm{Nlgn}^{+/+}$littermates. These results demonstrate that the effect of a loss-of-function mutation in Nlgn3 is dose dependent and, because Nlgn3 is an X-linked gene, less likely to affect females than males. In addition, $\mathrm{Nlgn}^{-/-}$ mice are likely modifying the social behavior of their littermates, suggesting that, as in males, social hierarchy or at least group inequality may exist in female laboratory mice. In contrast to $\mathrm{Nlgn} 3^{y /-}$ mice, young $\mathrm{Nlgn}^{-1-}$ mice show no sensitivity to the social environment. Importantly, these results indicate that the social environment has a sexually dimorphic effect on the phenotypes associated with ASD, which could in part explain the increased prevalence in boys versus girls in humans.

Our observation that the behavior of transgenic mice can affect that of their wild-type littermates, and vice versa, is a crucial parameter to take into account in the interpretation of experiments. Much evidence indicates that such a phenomenon may not be limited to $\mathrm{Nlgn} 3^{y /-}$ mice but could extend to other models. First, several genetic mouse models of ASD display social submission (Spencer et al., 2005; Yang et al., 2015a, 2015b) or courtship behavior deficits, potentially indicative of a social dominance phenotype (Kazdoba et al., 2016). Raising these mice with wild-type littermates could create similar social heterogeneity, and the associated phenotypes, to that of $\mathrm{Nlgn}^{y /-}$ mice and their wild-type littermates. Second, the behavioral phenotype of $N / g n 3^{y /-}$ is associated with dysfunctions of Pvalb-expressing interneurons [Polepalli et al. (2017) and Figs. 4 and 5] and type 1 mGluRs (Baudouin et al., 2012). Several studies have suggested that, despite the heterogeneity of genetic factors causing ASD, similar pathophysiological phenotypes converge on common behavioral phenotypes (Gogolla et al., 2009, 2014; Auerbach et al., 2011; Baudouin, 2014). Several mouse models of ASD show cellular (Gogolla et al., 2014; Karayannis et al., 2014; Ito-Ishida et al., 2015) and molecular (Bear et al., 2004; Tian et al., 2015; Wang et al., 2016) pathophysiology similar to $\mathrm{Nlgn} 3^{y /-}$ mice, associated with a common social behavior phenotype; therefore, these transgenic mice could also modify the behavior of their wild-type littermates. Our observation that the phenotype of $\mathrm{Nlgn} 3^{y /-}$ mice modifies the social behavior of their $N / g n 3^{y /+}$ littermates implies that using wild-type littermates as unique controls for experiments with animal models may lead to false interpretations of results. Therefore, these findings could profoundly affect the interpretation of experiments using mouse models of ASD, and we strongly recommend that standard laboratory practice should take into account the potential confounding effect of social heterogeneity by including independent nonlittermate wild-type mice as additional controls.

\section{References}

Auerbach BD, Osterweil EK, Bear MF (2011) Mutations causing syndromic autism define an axis of synaptic pathophysiology. Nature 480:63-68. CrossRef

Baudouin SJ (2014) Heterogeneity and convergence: the synaptic pathophysiology of autism. Eur J Neurosci 39:1107-1113. CrossRef Medline

Baudouin SJ, Gaudias J, Gerharz S, Hatstatt L, Zhou K, Punnakkal P, Tanaka KF, Spooren W, Hen R, De Zeeuw CI, Vogt K, Scheiffele P (2012) Shared synaptic pathophysiology in syndromic and nonsyndromic rodent models of autism. Science 338:128-132. CrossRef

Bear MF, Huber KM, Warren ST (2004) The mGluR theory of fragile $X$ mental retardation. Trends Neurosci 27:370-377. CrossRef

Belforte JE, Zsiros V, Sklar ER, Jiang Z, Yu G, Li Y, Quinlan EM, Nakazawa K (2010) Postnatal NMDA receptor ablation in corticolimbic interneurons confers schizophrenia-like phenotypes. Nat Neurosci 13:76-83. CrossRef Medline

Billingslea EN, Tatard-Leitman VM, Anguiano J, Jutzeler CR, Suh J, Saunders JA, Morita S, Featherstone RE, Ortinski PI, Gandal MJ, Lin R, Liang Y, Gur RE, Carlson GC, Hahn CG, Siegel SJ (2014) Parvalbumin cell ablation of NMDA-R1 causes increased resting network excitability with associated social and self-care deficits. Neuropsychopharmacology 39:1603-1613. CrossRef Medline

Caligioni CS (2009) Assessing reproductive status/stages in mice. Curr Protoc Neurosci Appendix 4:Appendix 4I. CrossRef Medline

C Yuen RK, et al., (2017) Whole genome sequencing resource identifies 18 new candidate genes for autism spectrum disorder. Nat Neurosci 20:602-611. CrossRef

Deacon RM (2006) Digging and marble burying in mice: simple methods for in vivo identification of biological impacts. Nat Protoc 1:122-124. CrossRef Medline

Del Pino I, García-Frigola C, Dehorter N, Brotons-Mas JR, AlvarezSalvado E, Martínez de Lagrán M, Ciceri G, Gabaldón MV, Moratal D, Dierssen M, Canals S, Marín O, Rico B (2013) Erbb4 deletion from fast-spiking interneurons causes schizophrenia-like phenotypes. Neuron 79:1152-1168. CrossRef Medline

Fischer J, Hammerschmidt K (2011) Ultrasonic vocalizations in mouse models for speech and socio-cognitive disorders: insights into the evolution of vocal communication. Genes Brain Behav 10:17-27. CrossRef Medline

Garner JP, Gaskill BN, Pritchett-Corning KR (2016) Two of a kind or a full house? Reproductive suppression and alloparenting in laboratory mice. PLoS One 11:e0154966. CrossRef Medline

Gogolla N, Takesian AE, Feng G, Fagiolini M, Hensch TK (2014) Sensory integration in mouse insular cortex reflects GABA circuit maturation. Neuron 83:894-905. CrossRef Medline

Gogolla N, LeBlanc JJ, Quast KB, Südhof TC, Fagiolini M, Hensch TK (2009) Common circuit defect of excitatory-inhibitory balance in mouse models of autism. J Neurodev Disord 1:172-181. CrossRef

Greenberg GD, Howerton CL, Trainor BC (2014) Fighting in the home cage: agonistic encounters and effects on neurobiological markers within the social decision-making network of house mice (Mus musculus). Neurosci Lett 566:151-155. CrossRef Medline 
Hippenmeyer S, Vrieseling E, Sigrist M, Portmann T, Laengle C, Ladle DR, Arber S (2005) A developmental switch in the response of DRG neurons to ETS transcription factor signaling. PLOS Biol 3:e159. CrossRef Medline

Holy TE, Guo ZS (2005) Ultrasonic songs of male mice. PloS Biol 3:e386. CrossRef

Hurst JL, West RS (2010) Taming anxiety in laboratory mice. Nat Methods 7:825-826. CrossRef Medline

Ito-Ishida A, Ure K, Chen H, Swann JW, Zoghbi HY (2015) Loss of MeCP2 in parvalbumin-and somatostatin-expressing neurons in mice leads to distinct Rett syndrome-like phenotypes. Neuron 88:651-658. CrossRef Medline

Jamain S, Quach H, Betancur C, Råstam M, Colineaux C, Gillberg IC, Soderstrom H, Giros B, Leboyer M, Gillberg C, Bourgeron T, Paris Autism Research International Sibpair Study (2003) Mutations of the X-linked genes encoding neuroligins NLGN3 and NLGN4 are associated with autism. Nat Genet 34:27-29. CrossRef

Juntti SA, Tollkuhn J, Wu MV, Fraser EJ, Soderborg T, Tan S, Honda S, Harada N, Shah NM (2010) The androgen receptor governs the execution, but not programming, of male sexual and territorial behaviors. Neuron 66:260-272. CrossRef

Karayannis T, et al., (2014) Cntnap4 differentially contributes to GABAergic and dopaminergic synaptic transmission. Nature 511: 236-240. CrossRef Medline

Kazdoba TM, Leach PT, Crawley JN (2016) Behavioral phenotypes of genetic mouse models of autism. Genes Brain Behav 15:7-26. CrossRef Medline

Kazdoba TM, Leach PT, Silverman JL, Crawley JN (2014) Modeling fragile $X$ syndrome in the Fmr1 knockout mouse. Intractable Rare Dis Res 3:118-133. CrossRef Medline

Langford DJ, Crager SE, Shehzad Z, Smith SB, Sotocinal SG, Levenstadt JS, Chanda ML, Levitin DJ, Mogil JS (2006) Social modulation of pain as evidence for empathy in mice. Science 312: 1967-1970. CrossRef Medline

Lee E, Lee J, Kim E (2017) Excitation/inhibition imbalance in animal models of autism spectrum disorders. Biol Psychiatry 81:838-847. CrossRef Medline

Levy D, Ronemus M, Yamrom B, Lee YH, Leotta A, Kendall J, Marks S, Lakshmi B, Pai D, Ye K, Buja A, Krieger A, Yoon S, Troge J, Rodgers L, lossifov I, Wigler M (2011) Rare de novo and transmitted copy-number variation in autistic spectrum disorders. Neuron 70:886-897. CrossRef Medline

Polepalli JS, Wu H, Goswami D, Halpern CH, Südhof TC, Malenka RC (2017) Modulation of excitation on parvalbumin interneurons by neuroligin-3 regulates the hippocampal network. Nat Neurosci 20:219-229. CrossRef

Portmann T, et al., (2014) Behavioral abnormalities and circuit defects in the basal ganglia of a mouse model of $16 p 11.2$ deletion syndrome. Cell Rep 7:1077-1092. CrossRef Medline

Radyushkin K, Hammerschmidt K, Boretius S, Varoqueaux F, ElKordi A, Ronnenberg A, Winter D, Frahm J, Fischer J, Brose N, Ehrenreich H (2009) Neuroligin-3-deficient mice: model of a monogenic heritable form of autism with an olfactory deficit. Genes Brain Behav 8:416-425. CrossRef

Rapanelli M, Frick LR, Pittenger C (2017) The role of interneurons in autism and Tourette syndrome. Trends Neurosci 40:397-497.

Rothwell PE, Fuccillo MV, Maxeiner S, Hayton SJ, Gokce O, Lim BK, Fowler SC, Malenka RC, Sudhof TC (2014) Autism-associated neuroligin-3 mutations commonly impair striatal circuits to boost repetitive behaviors. Cell 158:198-212. CrossRef Medline

Sanders SJ, et al., (2011) Multiple recurrent de novo CNVs, including duplications of the $7 q 11.23$ Williams syndrome region, are strongly associated with autism. Neuron 70:863-885. CrossRef Medline

Sapolsky RM (2005) The influence of social hierarchy on primate health. Science 308:648-652. CrossRef Medline

Saunders JA, Tatard-Leitman VM, Suh J, Billingslea EN, Roberts TP, Siegel SJ (2013) Knockout of NMDA receptors in parvalbumin interneurons recreates autism-like phenotypes. Autism Res 6:6977. CrossRef
Schuhr B (1987) Social structure and plasma corticosterone level in female albino mice. Physiol Behav 40:689-693. Medline

Smith ML, Hostetler CM, Heinricher MM, Ryabinin AE (2016) Social transfer of pain in mice. Sci Adv 2:e1600855. CrossRef Medline

Spencer CM, Alekseyenko O, Serysheva E, Yuva-Paylor LA, Paylor R (2005) Altered anxiety-related and social behaviors in the Fmr1 knockout mouse model of fragile X syndrome. Genes Brain Behav 4:420-430. CrossRef Medline

Tanaka KF, Ahmari SE, Leonardo ED, Richardson-Jones JW, Budreck EC, Scheiffele P, Sugio S, Inamura N, Ikenaka K, Hen R (2010) Flexible accelerated STOP tetracycline operator-knockin (FAST): a versatile and efficient new gene modulating system. Biol Psychiatr 67:770-773. CrossRef Medline

Tian D, Stoppel LJ, Heynen AJ, Lindemann L, Jaeschke G, Mills AA, Bear MF (2015) Contribution of mGluR5 to pathophysiology in a mouse model of human chromosome 16p11.2 microdeletion. Nat Neurosci 18:182-184. CrossRef Medline

Tsai PT, Hull C, Chu Y, Greene-Colozzi E, Sadowski AR, Leech JM, Steinberg J, Crawley JN, Regehr WG, Sahin M (2012) Autistic-like behaviour and cerebellar dysfunction in Purkinje cell Tsc1 mutant mice. Nature 488:647-651. CrossRef

Van Loo PL, Van Zutphen LF, Baumans V (2003) Male management: coping with aggression problems in male laboratory mice. Lab Animals 37:300-313. CrossRef Medline

Vargas-Pérez H, Sellings L, Grieder T, Díaz JL (2009) Social dominance rank influences wheel running behavior in mice. Neurosci Lett 457:137-140. CrossRef Medline

Vom Saal FS, Franks P, Boechler M, Palanza P, Parmigiani S (1995) Nest defense and survival of offspring in highly aggressive wild Canadian female house mice. Physiol Behav 58:669-678. Medline

Wang F, Zhu J, Zhu H, Zhang Q, Lin Z, Hu H (2011) Bidirectional control of social hierarchy by synaptic efficacy in medial prefrontal cortex. Science 334:693-697. CrossRef Medline

Wang SS, Kloth AD, Badura A (2014) The cerebellum, sensitive periods, and autism. Neuron 83:518-532. CrossRef Medline

Wang X, et al., (2016) Altered mGluR5-Homer scaffolds and corticostriatal connectivity in a Shank3 complete knockout model of autism. Nat Commun 7:11459. CrossRef

Wöhr M, Orduz D, Gregory P, Moreno H, Khan U, Vörckel KJ, Wolfer DP, Welzl H, Gall D, Schiffmann SN, Schwaller B (2015) Lack of parvalbumin in mice leads to behavioral deficits relevant to all human autism core symptoms and related neural morphofunctional abnormalities. Translat Psychiatr 5:e525. CrossRef Medline

Yang M, Lewis F, Foley G, Crawley JN (2015a) In tribute to Bob Blanchard: Divergent behavioral phenotypes of 16p11.2 deletion mice reared in same-genotype versus mixed-genotype cages. Physiol Behav 146:16-27.

Yang M, Perry K, Weber MD, Katz AM, Crawley JN (2011) Social peers rescue autism-relevant sociability deficits in adolescent mice. Autism Research 4:17-27. CrossRef Medline

Yang M, Mahrt EJ, Lewis F, Foley G, Portmann T, Dolmetsch RE, Portfors CV, Crawley JN (2015b) 16p11.2 deletion syndrome mice display sensory and ultrasonic vocalization deficits during social interactions. Autism Res 8:507-521.

Ylisaukko-oja T, Rehnström K, Auranen M, Vanhala R, Alen R, Kempas E, Ellonen P, Turunen JA, Makkonen I, Riikonen R, Nieminenvon Wendt T, von Wendt L, Peltonen L, Järvelä I (2005) Analysis of four neuroligin genes as candidates for autism. Eur J Hum Genet 13:1285-1292. CrossRef Medline

Zhang B, Chen LY, Liu X, Maxeiner S, Lee SJ, Gokce O, Südhof TC (2015) Neuroligins sculpt cerebellar Purkinje-cell circuits by differential control of distinct classes of synapses. Neuron 87:781-796. CrossRef Medline

Zou D, Chen L, Deng D, Jiang D, Dong F, McSweeney C, Zhou Y, Liu L, Chen G, Wu Y, Mao Y (2016) DREADD in parvalbumin interneurons of the dentate gyrus modulates anxiety, social interaction and memory extinction. Current Mol Med 16:91-102. Medline 